pag

Business School

WORKING PAPER SERIES

\begin{tabular}{|l|l} 
Working Paper & $\begin{array}{l}\text { Revisiting the New Normal Hypothesis } \\
2015-628\end{array}$ \\
$\begin{array}{l}\text { Bertrand Candelon } \\
\text { Alina Carare } \\
\text { Keith Miao }\end{array}$
\end{tabular}

http://www.ipag.fr/fr/accueil/la-recherche/publications-WP.html

IPAG Business School

184, Boulevard Saint-Germain

75006 Paris

France

IPAG working papers are circulated for discussion and comments only. They have not been peer-reviewed and may not be reproduced without permission of the authors. 


\title{
Revisiting the New Normal Hypothesis
}

\author{
Bertrand Candelon $^{1} \quad$ Alina Carare $^{2} \quad$ Keith Miao $^{3}$
}

August 31, 2015

\begin{abstract}
The paper estimates the impact of crises on output growth and augments Cerra and Saxena's (2008) analysis by extending the data until 2010, and by taking into account globalization and contagion effects. The paper finds that the decline in output growth rates following currency, banking and stock market crises are much larger in the sample ending in 2010, than in the one ending in 2001. The results are robust across different specifications, including by factor augmenting the panel through the extraction of principal components from the output growth to account for globalization, and by using various crises databases. In addition, the paper finds that globalization has benefitted economic growth in the long run, but those gains have been diminishing in the new millennium. Moreover, globalization also amplifies the negative effects of crises, especially for upper middle and high income OECD countries also starting with the new millenium. As such, lower output growth is to be expected as the new norm, especially in advanced economies for a lot longer than what would have been expected in the usual cyclical recovery, confirming El-Erian and PIMCO's (2009) statement on a "new normal". Finally, the factor augmenting panel also allows us to show in a new way that there are thresholds effects of finance and globalization on growth.
\end{abstract}

Keywords: New Normal Hypothesis; Financial crises; Banking crisis; Output growth. J.E.L. Codes: F30; F41

\footnotetext{
${ }^{1}$ Insti7/IPAG Chair Professor in financial stability and systemic risks, 184 boulevard Saint Germain, 75006 Paris, France.

${ }^{2}$ International Monetary Fund, 700 19th Street, NW, Washington, DC 20431, U.S.A.

${ }^{3}$ formerly International Monetary Fund.

${ }^{4}$ The authors would like to thank Joshua Aizenman, Jorg Breitung, Yin-Wong Cheung and Jakob de Haan, the guest editors of special issue on "New Normal in the Post-Crisis Era" of the Journal of International Money and Finance, our discussant Daniel Law, an anonymous referees, and the participants at the 9th International Workshop of MIFN at Osaka University, the 2nd van Gogh grang meeting in Paris and the 2015 IBRGM meeting in Nice for helpful comments. Support from Xi Zhang is gratefully acknowledged. The usual disclaimers apply: the paper does not represent the views or policies of the International Monetary Fund staff or its Executive Board.
} 


\section{Introduction}

At the beginning of the global financial crisis of 2008, and even more so seven years into it, economists are interested in how crises affect output growth. The April 2015 IMF's World Economic Outlook stressed the prospects of uneven growth across regions and income levels, and the IMF Managing Director warned that the new mediocre will become the new reality, unless all policy space and levers would be utilized.

Does this mean that the literature by now settled on firm evidence of a "new normal"? The term, coined by M. El-Erian and PIMCO in 2009, refers to lower output and employment growth to be expected as the new norm, especially in advanced economies where consumers needed to deleverage extensively. This was expected if not permanently, at least for a lot longer than what would have been expected in the usual cyclical recovery.

Systematic and unambiguous evidence of a "new normal" is important for policy debate and for the construct of theoretical models. In a "new normal" the recommended policies would be stabilization policies accompanied by strong structural reforms, such that long run effects of negative short run developments are mitigated. Moreover, the "new normal" implies that models assuming a deterministic steady-state (like most of the DSGE models do) and log-linearization around this long run equilibrium would be unable to capture well the dynamic of the crisis, and a new generation of theoretical models would be needed, to capture the new stationary equilibrium implied by the "new normal".

This paper focuses on sifting systematically through the empirical evidence of the existence or absence of a "new normal", interpreted as the decline in output growth following a crisis, especially the most recent one. The paper does not quantify the output loss due to the crisis, which is usually estimated as the difference between actual output and the potential output that would prevail after the crisis. The latter is analyzed and quantified in IMF (2015), Ball (2014) and IMF (2009). The paper also does not measure the length of the recovery, or its pattern, but if crises have a long impact on output growth, and if they do, in which case, as in Cerra and Saxena (2008). Most importantly, we are interested in seeing how these results have changed looking at the years after the global financial crisis of 2008.

In the large literature of the impact of crises on output growth Cerra and Saxena (2008, CS hereafter) is a seminal paper because it debunked the myth of output recovering quickly from all recessions, especially the ones following crises, and it emphasized that the weakest recoveries occur after banking crises. They simulated the output loss by using impulse response function, ten years out, calculated using coefficients from a growth regression. They regressed GDP growth on its lags and individual country crisis dummies using panel country fixed effects with unbalanced panels with data from 190 countries, from 1960 until 2001. Their results are presented across different income levels, and areas, for currency, banking, and twin financial (currency and banking) crises. They also show the impact of civil wars 
and stronger executive power.

This paper proposes three extensions of the CS framework to expand and refine the estimation of the impact of crises on output growth, and hence to investigate closely the "new normal" hypothesis. First, the paper extends the sample to 2010 and investigates if the negative impact of crises on output growth would be larger than in the sample ending in 2001, thus corroborating the "new normal" hypothesis. Second, we concentrate primarily on the role of economic crises, and investigate the effect of more crises: besides currency and banking crises, we also investigate the effect of stock market, debt, and inflation crises on output growth. Third, we control for globalization and contagion effects, to have a more precise test of the "new normal" hypothesis.

We systematically sift through evidence of the existence or not of a "new normal", by investigating the effect of crises across various samples ending at different points in time. We start with the 1980s because the evidence points to a concentration of banking crises after this date, e.g. see Oulton and Barriel (2013). We also investigate the impact of crises on output growth across various income levels and geographical areas, like in Cerra and Saxena (2008), to deepen our understanding of the issues. To avoid biases we use balanced panels with output growth rates and the crises dummies from Reinhart and Rogoff (2009) from 100 countries for 1960-2010. For robustness we also use crises dummies as in Laeven and Valencia (2013), and we analyze the results for high income OECD countries in a sample ending in 2014.

The paper finds unambiguously that crises affect negatively output growth. When we regress real GDP growth on its own lags, and a set of individual country specific dummies, we find that the coefficients of the crises dummies are negative, and tend to be consistently significant. Moreover, the paper corroborates evidence of a "new normal", by finding that the negative effects of the currency, banking and stock market crises are stronger and higher when including data from the 2008 crisis. Although banking crises have a negative significant effect starting with 1980, especially for high-income OECD countries, once we control for globalization the banking crisis is significant only in the post-2008 sample. While currency crises also have a negative effect on output growth, they are significant only with 2000 (including when we control for globalization), especially for upper middle income countries. Stock market crises have a significant negative effect on output growth, regardless of the time period considered, and even when we control for globalization and contagion.

For globalization we extract the principal components from the output growth. The "new normal" hypothesis is also estimated considering a factor augmented panel, in which we regress output growth on these principal components, besides the crises dummies. This approach avoids the overestimation of the crises impact, and thus a bias towards the new normal hypothesis. In addition, for robustness we include spatial factors á la Anselin (1999), 
allowing for crisis diffusion strongly across countries in the short run (as in Forbes and Rigobon, 2002, Giavazzi and Perotti, 1998).

As we find a principal component that is negatively correlated with the banking, and currency crises, and that component has a positive impact on output growth on average over the sample, we interpret this to be the role of globalization, especially financial integration and liberalization. Moreover, once we incorporate this component in our output growth regressions we find that banking crisis have a negative effect on output growth, only in the extended sample, and more importantly mostly for high income OECD countries. These results not only support the "new normal" hypothesis as stated by El-Erian and PIMCO in 2009, but also Cecchetti's 2012 tentative conclusion that globalization is good but not always. In addition, as this component's positive impact on growth is lower in the sample ending in 2010 than in the one ending in 2001, the results imply like in Aizenman and others (2015), Sahay and others (2015), and Rousseau and Wachtel (2011) that there is a non-linear relationship of finance and growth, where the development of financial sector benefits the real sector up to a point, because thereafter there are diminishing marginal returns to financial development.

Hence the paper's contribution to literature is trifold. First, it presents unambiguous, systematic and comprehensive evidence of a "new normal", as stated by El-Erian and PIMCO (2009): lower output growth is the new norm, especially in advanced economies where consumers needed to deleverage extensively for a lot longer than what would have been expected in an usual cyclical recovery. That will continue, unless as Obstfeld (2011) noted, the existing informational and institutional structure for global policymaking improves. Second, by factor augmenting the panel we show a new, more refined way to estimate the impact of crises on output growth. Third, this method also allows to show new evidence for threshold effects for the finance impact on real output growth, and of financial integration impact on growth. Moreover, to the best of our knowledge, the paper links for the first time these results, and therefore these strands of literature.

The rest of the paper is sketched as follows. In Section 2, we replicate the CS framework extending also data sample up to 2010. Sections 3 extends the model considering interdependence as well as contagion, while section 4 estimates the basic model, as well as the interdependent model across different sample periods. Section 5 expands the robustness checks, by extending the framework to account for differences in income levels. Section 6 ends with the robustness checks considering alternative crises dummy dating and the most recent observations. Section 7 concludes. 


\section{Testing for "new normal": extending the sample, the Cerra and Saxena approach}

In our estimation we follow CS and use a panel autoregressive representation of the output growth, expressed as follows:

$$
g_{i, t}=c+\sum_{j=1}^{4} \beta_{j} g_{i, t-j}+\sum_{j=1}^{4} \delta_{j} D_{i, t-j}+\eta_{i}+u_{i, t},
$$

where $g_{i, t}$ is the real GDP growth rate in country $i$ at time $t^{1}, u_{i, t}$ i.i.d. residuals and $c$ a constant. $D_{i, t-s}$ are a set of dummy crises and $\eta_{i}$ a country fixed effect to account for unobserved heterogeneity. To evaluate the long lasting effect on growth, CS use the coefficients obtained from this regression and consider impulse response functions (IRF) based on equation (1). If the IRF is significantly different from zero then they conclude in favor of persistent output losses.

In our estimation, the "new normal" hypothesis is supported when the coefficients associated with the dummy variables are significantly different from 0 , under different specifications and sets of variables used, especially when including data post-2008. In such a case, it can be argued that a crisis turns out to have a significant impact on output growth as well as a permanent impact on GDP levels.

The data used in this paper covers 100 countries from 1960 to 2010 on a yearly frequency. Our sample size is smaller than the one used by CS (190 countries), but doing so we are able to handle a balanced panel, avoiding statistical biases associated with unbalanced representation. Like in CS we download the GDP growth rates from the World Bank World Development Indicators (WDI) Database. The list of countries is provided in Appendix 1. Like in CS we use the World Bank group classification for income levels, and present the analysis first for the entire sample in this section, and in section 5 by income group. Our balanced sample consists of countries of various income levels, and geographical distribution, as follows: nineteen are low income countries, twenty six are lower middle income countries, twenty two are upper middle income countries, twenty two are high income OECD countries, and eleven high income non-OECD countries. Of those thirty three are African countries, sixteen are Asian countries, thirteen are European countries, sixteen are Latin American countries, and twenty two countries are from the rest of the world.

We use the crisis variables downloaded from Reinhart and Rogoff's website ( $h t t p$ : //www.reinhartandrogoff.com/data/), which are available for all our sample: 100 coun-

\footnotetext{
${ }^{1}$ Implementing the traditional panel unit root tests proposed by Im, Pesaran and Shin (2003) and Levin, Lee and Chu (2002), the null hypothesis of unit root is rejected and we consider the real GDP growth rate as stationary. Results are available from the authors upon request.
} 
tries, from 1960 until 2010. These are crisis dummies, which date and track banking crises (BAN), currency crashes (CUR), sovereign domestic (DOM) or external debt default or restructuring (EXT), the year a country received its independence (IND), inflation crises (INF), and stock market crashes (STO). The crises data is summarized in Appendix 2, with the years of crises for various countries, grouped per type of crisis, and income level. The crises are defined in Appendix 3, following Reinhart and Rogoff (2009). ${ }^{2}$ Later in the paper, in the robustness section we used a different crisis database.

A preliminary correlation analysis reveals that crises dummies are only weakly correlated (less than 20\%). It is thus possible to analyze the impact of a twin crisis (banking and currency crisis simultaneously) as the sum of the effects of the banking and the currency ones. Moreover, as Hutchison and Noy (2005) find, while the cumulative loss of both types of crises on real activity is large, there are no additional feedbacks or interactive effects associated with twin crises further damaging the economy. Hence, we also used these banking and currency crises dummies simultaneously in the estimation. We have not added extra terms to account for twin crises, and such effects could be considered as the sum of the two coefficients.

The lag order $(j)$ used by CS is fixed to 4 . Similarly to CS we consider 4 lags but, in addition, we also consider a more restrictive model with only one lag. Each system is estimated considering a fixed country effect and using a Maximum Likelihood. Standard errors are reported after a White correction for heteroskedasticity.

Results for both samples $(1960-2001$ and 1960 - 2010) are gathered in Table 1 . We first notice that including 4 lags is not statistically supported by the information criteria and the likelihood ratio test. We nevertheless decide to consider both specifications in the rest of the paper, so as to have a relative comparison with CS.

We found as in CS that crises dummies are significantly different from zero, and have a negative sign. More precisely, banking and stock market crises have the highest significant negative effect on real activity (GDP growth rate) whatever the sample length, and specification (number of lags) considered. The other types of crises (domestic, external, inflation) and the year of independence do not appear to have an effect on real activity. The role played by currency crisis is particularly interesting. In the first sample (until 2001), its effect on output growth is only significant at 10\%, and only for the 1 lag specification, indicating a relatively minor impact on real activity. However, the coefficient becomes highly significant when the last ten years and the recent financial crisis are taken into account. Such a result

\footnotetext{
${ }^{2}$ Whereas crisis dummies are normally binary, Reinhart and Rogoff (2009) allocate in few cases the value of 2 for severe crises. We use the original database (with values of 0,1 , and 2 for the crises dummies) in the main analysis of the paper. When we transformed the original database into a binary one, i.e. substituting the 2 by a 1 , the value of the estimators were only marginally affect. The corresponding tables for estimations with dummy crises values of 0 and 1 only are available from the authors upon request.
} 
is driven by the exchange rates movements that have taken place during the 2008 crisis and supports the findings previous studies (Glick and Hutchinson, 2000, Bordo and others, 2001, among others) which proved that banking crises are more and more often coupled with currency crises and their ${ }^{3}$ real impact becomes important.

As the coefficient on the lag GDP growth rate is significantly different than zero, it means that following a negative shock (regular recession), an economy will eventually revert to its average long run growth rate. However, in the presence of a crisis this period is longer (when that dummy coefficient is negative and significant different from zero). In addition, as the coefficient of the crises dummies increase in the post-2008 sample, it means that they subtract now even more from GDP growth than in the earlier periods, making this growth rate mean reversion even slower. As a result, after the most recent financial crisis it does take a lot longer for output growth rates to revert to their long run averages. ${ }^{4}$.

The estimation results confirm our intuition that by extending the sample to include the data from the latest financial crisis, we will found increased impact of crisis on output growth, and hence evidence of a "new normal". For the 1 lag specification, the negative impact of crises on GDP growth increases from the sample ending in 2001 to the one ending in 2010 as follows: for stock market crises the size of the dummy crisis coefficient increases from -1.65 to -1.76 , for currency crises from -0.48 to -0.63 (with increased significance), and for banking crises from -0.48 to -0.66 . This result supports unambiguously the "new normal" hypothesis: crises reduce GDP growth, and more so after the 2008 crisis. $^{5}$

We also report the estimated fixed effect in Figure 1 at the end of the paper. It turns out that these fixed effects differ highly across countries (from -2.5 to +3.9 ) revealing huge regional disparities. This paves the way for the heterogenous panel analysis presented in Section 5 .

\footnotetext{
${ }^{3}$ These crises are labeled twin crises.

${ }^{4}$ What we identify are on average the impact of the crises on GDP growth, without disentangling how much of the growth was alleviated by policy responses. That is the scope of different type of papers, see for example Hutchison and others (2010)

${ }^{5} \mathrm{~A}$ simple simulation exercise reveals that after 10 years after the occurrence of a banking crisis, output is on average reduced by $1.082 \%$ using the coefficients from the $1960-2010$ sample and by $0.399 \%$ using the model for the period 1960 - 2001. Impulse response functions are not reported to save space but are available from the authors upon request.
} 
Table 1: New Normals Testing

\begin{tabular}{|c|c|c|c|c|c|c|c|c|}
\hline & $\begin{array}{r}1960 \\
\text { coeff } s\end{array}$ & $\mathrm{se}$ & $\begin{array}{c}-2001 \\
c o \hat{e f f s}\end{array}$ & se & $\begin{array}{r}1960 \\
\text { coeffs }\end{array}$ & se & $\begin{array}{r}-2010 \\
\text { coeffs } \\
\end{array}$ & se \\
\hline$g_{-1}$ & 0.275 & $0.058^{* * *}$ & 0.272 & $0.058^{* * *}$ & 0.285 & $0.045^{* * *}$ & 0.282 & $0.045^{* * *}$ \\
\hline$g_{-2}$ & 0.019 & 0.035 & 0.018 & 0.034 & 0.029 & 0.029 & 0.026 & 0.028 \\
\hline$g_{-3}$ & 0.018 & 0.029 & 0.018 & 0.029 & 0.023 & 0.030 & 0.023 & 0.030 \\
\hline$g_{-4}$ & -0.049 & $0.018 * * *$ & -0.047 & $0.018 * * *$ & -0.036 & 0.035 & -0.035 & $0.034^{* * *}$ \\
\hline $\mathrm{BAN}(-1)$ & -0.762 & $0.354 * * *$ & -0.484 & $0.281 * * *$ & -1.143 & $0.367 * * *$ & -0.663 & $-0.268^{* * *}$ \\
\hline $\operatorname{BAN}(-2)$ & 0.330 & 0.358 & & & 0.605 & 0.341 & & \\
\hline $\operatorname{BAN}(-3)$ & 0.394 & 0.344 & & & 0.317 & 0.254 & & \\
\hline $\mathrm{BAN}(-4)$ & -0.412 & 0.263 & & & -0.376 & 0.277 & & \\
\hline CUR(-1) & -0.428 & 0.269 & -0.480 & $0.255^{*}$ & -0.606 & 0.267 & -0.628 & $0.276^{* * *}$ \\
\hline CUR(-2) & -0.120 & 0.284 & & & 0.140 & 0.241 & & \\
\hline CUR $(-3)$ & 0.177 & 0.250 & & & 0.081 & 0.221 & & \\
\hline CUR $(-4)$ & -0.220 & 0.228 & & & -0.181 & 0.227 & & \\
\hline $\operatorname{DOM}(-1)$ & -0.645 & 0.798 & -0.574 & 0.785 & -0.180 & 0.925 & -0.147 & 0.715 \\
\hline $\operatorname{DOM}(-2)$ & 1.276 & 0.925 & & & 0.301 & 1.266 & & \\
\hline $\operatorname{DOM}(-3)$ & -2.060 & $1.064 * *$ & & & -0.973 & 0.981 & & \\
\hline $\operatorname{DOM}(-4)$ & 0.534 & 0.924 & & & 0.332 & 0.587 & & \\
\hline $\operatorname{EXT}(-1)$ & 0.081 & 0.444 & -0.240 & 0.252 & -0.151 & 0.376 & -0.314 & 0.314 \\
\hline $\operatorname{EXT}(-2)$ & -0.188 & 0.422 & & & -0.034 & 0.401 & & \\
\hline $\operatorname{EXT}(-3)$ & -0.014 & 0.354 & & & -0.068 & 0.363 & & \\
\hline $\operatorname{EXT}(-4)$ & -0.172 & 0.311 & & & -0.147 & 0.416 & & \\
\hline $\operatorname{IND}(-1)$ & 1.476 & 4.696 & -0.326 & 0.601 & 1.899 & 5.422 & -0.033 & 0.616 \\
\hline $\operatorname{IND}(-2)$ & -2.164 & 5.440 & & & -2.196 & 2.809 & & \\
\hline $\operatorname{IND}(-3)$ & 1.320 & 3.731 & & & 1.292 & 2.487 & & \\
\hline $\operatorname{IND}(-4)$ & -0.972 & 2.344 & & & -1.146 & 2.215 & & \\
\hline $\operatorname{INF}(-1)$ & 0.070 & 0.315 & -0.058 & 0.240 & -0.004 & 0.250 & 0.006 & 0.290 \\
\hline $\operatorname{INF}(-2)$ & 0.206 & 0.393 & & & 0.218 & 0.367 & & \\
\hline $\operatorname{INF}(-3)$ & -0.602 & 0.369 & & & -0.477 & 0.435 & & \\
\hline $\operatorname{INF}(-4)$ & 0.100 & 0.298 & & & 0.075 & 0.324 & & \\
\hline $\operatorname{STO}(-1)$ & -1.834 & $0.278 * * *$ & -1.653 & $0.526^{* * *}$ & -2.022 & $0.280 * * *$ & -1.759 & $0.270^{* * *}$ \\
\hline $\operatorname{STO}(-2)$ & 0.504 & 0.264 & & & 0.725 & 0.284 *** & & \\
\hline $\operatorname{STO}(-3)$ & -0.230 & 0.259 & & & -0.094 & 0.297 & & \\
\hline $\operatorname{STO}(-4)$ & 0.360 & 0.195 & & & 0.391 & 0.191 & & \\
\hline $\mathrm{C}$ & 3.343 & $0.527 * * *$ & 3.360 & $0.526^{* * *}$ & 3.060 & 2.718 & 3.103 & 2.689 \\
\hline $\mathrm{Lk}$ & $-11,384.22$ & & $-11,389.87$ & & $-14,200.57$ & & $-14,209.09$ & \\
\hline AIC & 6.271 & & 6.262 & & 6.154 & & 6.149 & \\
\hline BIC & 6.350 & & 6.329 & & 6.337 & & 6.203 & \\
\hline
\end{tabular}

Notes: This table reports the results of the estimations of model (1) including fixed country effect and using Maximum Likelihood methods. Standard errors are reported after a White correction. $* * *$ indicates significant estimators at $1 \%, * *$ at $5 \%, *$ at $10 \%$. 


\section{Testing for "new normal": taking into account for interdependence and contagion}

\subsection{Globalization (factor augmented panel)}

Trade and financial integration, often denominated as globalization, constitute the dominating features among the world economy in the past decades. Integration has been characterized by the creation of common trade areas (as the European Common Market or the North-American Free Trade Area), and since the end of the 1980's by the development of pan-continental banking organizations. Obstefld and Taylor (2004) document the long-run trends in globalization, and Philippon and Reshef (2013) note that there is "a common suggestion that the growth of financial sector is linked to globalization". Potential negative consequences of globalization have also been documented. Kose and others (2009) provide a unified conceptual framework of the benefits and also of the risks of financial globalization and growth, especially for emerging market countries. Glick and Rose (1999) stresses the role of trade in the regional diffusion of currency crises whereas Rijckeghem and Weder (2001, 2003) insist on the role of the financial and banking systems in the transmission of crisis to real economies around the world.

By omitting to include the structural linkages in growth due to globalization would lead to heavy estimation bias in (1) due to the presence of cross-sectional dependence. Pesaran (2006) and Bai (2009) proved and exhibit such biases. They recommend to augment the panel by including common factors. We follow therefore these new econometric developments, and include common factors in the panel regressions. By doing so we expect that using a factor augmented panel will modify the significance and/or the size of the coefficients for the crisis variables, while also affecting the constant. More precisely, our intuition is that by adding factors the evidence for the "new normal" hypothesis found in the previous section might be somewhat weakened. That is because financial integration while benefitting growth over the long run, might also exacerbate crises and their negative real effects (see Kose and others, 2009). Hence, we expect that (i) the coefficient of the new added factors might be positive, (ii) the introduction of such factors may lower the constant coefficient, as output growth in the good times might be a common phenomenon, and that (iii) some coefficients for the crises dummies might be lower. The latter does not imply that crises effects are weaker, but that after accounting of the positive long-run effects of globalization, country specific crises have a lower effect on real activity than previously estimated.

To augment our panel, we use the principal component method suggested by Pesaran and others (2006) or Bai (2009). Once the $l$ static principal components $\tilde{P} C_{l}$, with $l=1, \ldots m<n$ 
Table 2: Correlation analysis of the principal components

\begin{tabular}{rrrr}
\hline \hline & PC1 & PC2 & PC3 \\
\hline BANKING & -0.162 & 0.015 & 0.007 \\
& $(-11.703)$ & $(1.102)$ & $(0.503)$ \\
CURRENCY & -0.076 & 0.056 & -0.027 \\
& $(-5.460)$ & $(4.026)$ & $(-1.956)$ \\
DOMESTIC & -0.076 & 0.022 & 0.003 \\
& $(-5.415)$ & $(1.600)$ & $(0.227)$ \\
EXTERNAL & -0.114 & 0.082 & 0.006 \\
& $(-8.168)$ & $(5.846)$ & $(0.407)$ \\
INFLATION & -0.083 & 0.103 & 0.001 \\
& $(-5.951)$ & $(7.396)$ & $(0.100)$ \\
INDEPENDE. & 0.004 & 0.005 & -0.007 \\
& $(0.311)$ & $(0.359)$ & $(-0.494)$ \\
STOCK & -0.007 & -0.026 & -0.002 \\
& $(-0.490)$ & $(-1.871)$ & $(-0.158)$ \\
\hline \hline
\end{tabular}

Notes: This table reports the correlation between the first three principal components and the crisis dummies. $t$-statistics are reported between parentheses bellow the correlations.

extracted from the output growth series, model(1) can be rewritten as:

$$
g_{i, t}=a_{i, t}+\sum_{j=1}^{4} \beta_{j} g_{i, t-j}+\sum_{j=0}^{4} \delta_{j} D_{i, t-j}+\sum_{j=0}^{p} \sum_{l=1}^{m} \gamma_{1, l} \tilde{P} C_{l, t-j}+\eta_{i}+\epsilon_{i, t} .
$$

To extract the principal components from the output growth series, we opt for the simple static approach. The extraction of the principal components reveals that the first three factors explain more than $60 \%$ of the total volatility (respectively $39.89 \%, 10.22 \%$ and $6.10 \%$ ). The higher order principal components only explain individually less than $5 \%$ and we thus decided not to consider them. At this stage, it is crucial to provide an interpretation for these principal components. To this aim, a simple correlation analysis between these principal components and the crisis variables is performed and reported in Table 2.

It appears that the first principal component $(P C 1)$ is the one which is the most related to the crises variables as its correlation is negative, and significantly different from zero except with the stock market crisis and the independence dummies. The highest correlations for this principal component is found with the banking crisis $(-0.16)$ and to a lesser extent with the external crisis dummy $(-0.11)$. We interpret this principal component term as being linked to the development of financial/banking sectors and therefore could be used as a proxy for the financial/banking interdependence between economies. To further confirm this intuition, we also calculate the correlation for a period prior to 1985 and found no significant link anymore 
between these variables ${ }^{6}$. This is consistent with Kose and others (2009) that summarize the literature and note that financial integration and financial liberalization started in the 1980s, and with it, an increase of incidence in financial crises.

The interpretation of the two other principal components is more difficult. $P C 2$ is slightly correlated with inflation, currency and external crises but in a positive way, which signals that other determinants should cause it, whereas $P C 3$ is only slightly correlated to currency crisis dummy. These last two principal components thus could be driven by mechanisms independent from the crisis (as technology or development).

As in the previous section, we can now estimate the panel augmented by the principal component factors, i.e. Equation (2). Similarly we consider specifications with one and 4 lags, and include a fixed country effect. We also use the Maximum Likelihood estimation method and report White corrected Standard errors. Results are gathered in Table 3.

We first observe that in all specifications the information criteria support the one lag specification. However, the likelihood ratio test does not reject the null hypothesis of 4 lags at $10 \%$ for the reduced sample and at $5 \%$ for the full sample. As such, we continue to present the results for 4 and 1 lags, but when we analyze the results and cite sizes of coefficients we will refer to the specification with one lag only, as before.

Principal component 1 is strongly significant throughout all specifications (except the third) and seems to be a good proxy for the development of the financial/banking interdependence between economies. Its significance indicates that output growth rates benefitted (positively) in the long run on average from a structural factor that we interpreted to be financial integration and financial sector development. As expected, once we found a significant positive coefficient for this principal component, the size of the constant decreases, compared to the results in Table 1 . Hence, globalization contributed positively to growth, on average, and taking into account of this structural factor refines our coefficients. Principal component 3 is also significant, but only for the 1960-2001 subsample. It also has a negative sign, making it more difficult to interpret, whereas PC2 is never statistically different from zero.

Next, our intuition that taking into account globalization will lower the significance of the crises dummies, and/or decrease the size of those coefficients, is very clearly corroborated by the banking crisis dummy. We notice that once we introduced PCs the banking crisis coefficient (i) is significant only in the full sample, and (ii) decreases when principal component factors are included". Nevertheless, these results continue to support our "new normal" hypothesis as consistent with El-Erian and PIMCO (2009): lower GDP growth rates expected post-2008 global financial crisis, as deleveraging needs to occur.

\footnotetext{
${ }^{6}$ Results are available from the authors upon request.

${ }^{7}$ E.g. -0.51 in the specification with PCs, vs -0.66 in the specification without PCs, for the $1960-2010$ one lag model).
} 
Table 3: New Normals Testing including Principal Component terms

\begin{tabular}{|c|c|c|c|c|c|c|c|c|}
\hline & $\begin{array}{r}1960 \\
\text { coeffs }\end{array}$ & se & $\begin{array}{c}-2001 \\
\text { coeffs }\end{array}$ & se & $\begin{array}{r}1960 \\
\text { coeffs }\end{array}$ & se & $\begin{array}{c}-2010 \\
\text { coeffs }\end{array}$ & se \\
\hline$g_{-1}$ & 0.262 & 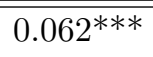 & 0.257 & $0.061 * * *$ & 0.278 & $0.045 * * *$ & 0.272 & $\overline{00.045 * * *}$ \\
\hline$g_{-2}$ & 0.007 & 0.037 & 0.016 & 0.035 & 0.018 & 0.029 & 0.026 & 0.028 \\
\hline$g_{-3}$ & 0.014 & 0.032 & 0.014 & 0.029 & 0.024 & 0.031 & 0.022 & 0.031 \\
\hline$g_{-4}$ & -0.057 & 0.018 & -0.054 & $0.017^{* * *}$ & -0.042 & 0.035 & -0.038 & $0.034^{* * *}$ \\
\hline$P C_{1,-1}$ & 6.316 & $2.787^{* * *}$ & 10.799 & $2.213^{* * *}$ & 3.563 & 5.737 & 7.223 & $4.388^{* * *}$ \\
\hline$P C_{1,-2}$ & 8.005 & $2.852^{* * *}$ & & & 6.978 & 4.350 & & \\
\hline$P C_{1,-3}$ & -1.062 & 2.832 & & & -2.129 & 4.385 & & \\
\hline$P C_{1,-4}$ & 2.069 & 3.046 & & & 1.812 & 3.895 & & \\
\hline$P C_{2,-1}$ & 0.588 & 0.749 & 0.369 & 0.616 & 0.572 & 1.065 & 0.578 & 0.781 \\
\hline$P C_{2,-2}$ & -0.168 & 0.810 & & & 0.025 & 0.923 & & \\
\hline$P C_{2,-3}$ & 1.062 & $0.649^{* * *}$ & & & -0.538 & 1.034 & & \\
\hline$P C_{2,-4}$ & 1.646 & $0.681^{* * *}$ & & & 0.614 & 0.843 & & \\
\hline$P C_{3,-1}$ & -1.528 & $0.676^{* * *}$ & -1.427 & $0.459 * * *$ & 0.285 & 0.839 & -1.306 & 0.989 \\
\hline$P C_{3,-2}$ & -2.075 & $0.847^{* * *}$ & & & -2.538 & 1.546 & & \\
\hline$P C_{3,-3}$ & 1.821 & $0.805^{* * *}$ & & & 1.617 & 1.305 & & \\
\hline$P C_{3,-4}$ & -2.035 & $0.713^{* * *}$ & & & -1.645 & 1.129 & & \\
\hline $\mathrm{BAN}(-1)$ & -0.547 & 0.347 & -0.192 & 0.276 & -1.017 & $0.360^{* * *}$ & -0.505 & $0.269^{* *}$ \\
\hline $\operatorname{BAN}(-2)$ & 0.425 & 0.346 & & & 0.641 & $0.326^{* * *}$ & & \\
\hline $\operatorname{BAN}(-3)$ & 0.450 & 0.338 & & & 0.380 & 0.243 & & \\
\hline $\operatorname{BAN}(-4)$ & -0.149 & 0.281 & & & -0.222 & 0.271 & & \\
\hline CUR(-1) & -0.456 & $0.265^{*}$ & -0.450 & $0.254^{*}$ & -0.668 & $0.250^{* * *}$ & -0.640 & $0.262^{* * *}$ \\
\hline CUR $(-2)$ & -0.077 & 0.266 & & & 0.137 & 0.234 & & \\
\hline CUR $(-3)$ & 0.237 & 0.262 & & & 0.145 & 0.218 & & \\
\hline CUR $(-4)$ & -0.181 & 0.223 & & & -0.160 & 0.229 & & \\
\hline $\operatorname{DOM}(-1)$ & -0.636 & 0.814 & -0.388 & 0.783 & -0.069 & 0.945 & -0.071 & 0.700 \\
\hline $\operatorname{DOM}(-2)$ & 1.532 & 0.941 & & & 0.492 & 1.292 & & \\
\hline $\operatorname{DOM}(-3)$ & -2.183 & $1.064^{*}$ & & & -1.089 & 0.977 & & \\
\hline $\operatorname{DOM}(-4)$ & 0.640 & $0.893^{* * *}$ & & & 0.418 & 0.582 & & \\
\hline $\operatorname{EXT}(-1)$ & 0.239 & 0.445 & -0.033 & 0.246 & -0.085 & 0.385 & -0.220 & 0.321 \\
\hline $\operatorname{EXT}(-2)$ & -0.153 & 0.412 & & & -0.022 & 0.403 & & \\
\hline $\operatorname{EXT}(-3)$ & -0.021 & 0.365 & & & -0.047 & 0.371 & & \\
\hline $\operatorname{EXT}(-4)$ & -0.012 & 0.316 & & & -0.067 & 0.421 & & \\
\hline $\operatorname{IND}(-1)$ & 1.415 & 5.065 & -0.267 & 0.498 & 2.094 & 5.397 & -0.020 & 6.071 \\
\hline $\operatorname{IND}(-2)$ & -2.552 & 6.161 & & & -2.528 & 3.148 & & \\
\hline $\operatorname{IND}(-3)$ & 0.883 & 3.965 & & & 0.797 & 2.682 & & \\
\hline $\operatorname{IND}(-4)$ & -0.483 & 2.567 & & & -0.728 & 2.496 & & \\
\hline $\operatorname{INF}(-1)$ & 0.219 & 0.311 & 0.084 & 0.498 & 0.060 & 0.257 & 0.022 & 0.278 \\
\hline $\operatorname{INF}(-2)$ & 0.196 & 0.374 & & & 0.166 & 0.341 & & \\
\hline $\operatorname{INF}(-3)$ & -0.553 & 0.380 & & & -0.480 & 0.435 & & \\
\hline $\operatorname{INF}(-4)$ & 0.180 & 0.300 & & & 0.092 & 0.309 & & \\
\hline $\operatorname{STO}(-1)$ & -1.662 & $0.284^{* * *}$ & -1.637 & $0.274^{* * *}$ & -1.960 & $0.261^{* * *}$ & -1.750 & $0.269^{* * *}$ \\
\hline $\operatorname{STO}(-2)$ & 0.382 & 0.265 & & & 0.683 & $0.249^{* * *}$ & & \\
\hline $\operatorname{STO}(-3)$ & -0.229 & 0.249 & & & -0.062 & 0.285 & & \\
\hline $\operatorname{STO}(-4)$ & 0.221 & 0.216 & & & 0.290 & 0.172 & & \\
\hline $\mathrm{C}$ & 1.305 & $0.541^{* * *}$ & 1.761 & $0.423^{* * *}$ & 1.828 & 2.709 & 2.168 & 2.735 \\
\hline $\mathrm{Lk}$ & $-11,353.79$ & & $-11,372.97$ & & $-14,176.26$ & & $-14,198.79$ & \\
\hline $\mathrm{AIC}$ & 6.261 & & 6.254 & & 6.149 & & 6.145 & \\
\hline $\mathrm{BIC}$ & 6.347 & & 6.323 & & 6.219 & & 6.201 & \\
\hline
\end{tabular}


The stock market crisis dummy remains negative and significant when the principal components are included, for all specifications. The currency crisis coefficient remains negative, and significant at 10 percent level in the 1961 - 2001 sample, and at 1 percent level in the full sample. The size of these coefficients decline slightly for the sample ending in 2001 compared to the specifications without PCs. All other dummy variables (domestic, external, independence and inflation) do not appear to be significant and thus to affect output growth permanently.

Another important result is that the coefficient of the principal component is lower in the sample ending in 2010 than the coefficient in the sample ending in 2001. This means that over the long run all countries' real GDP growth benefitted from financial sector development and integration, but those positive benefits started to decline after 2001. Moreover, negative effects are also recorded, due to the cost of currency crises post 2001, and of twin banking and currency crises post-2008. These results are in line with Kose and others (2009) that note the existence of thresholds effects on growth from financial globalization. Thus, we support empirically the claims by Obstfeld's (2011) that as long as regulation and supervision does not catch up with financial integration, we reached the point where financial globalization will subtract from output growth.

Figure $1 \mathrm{~b}$ shows the fixed effect estimators and reveals that they have a similar magnitude with those obtained without including the principal components.

All in all, taking into account the global interdependence refined our coefficients, and confirmed the main results as being robust.

\subsection{Contagion}

Taking into account the interdependence between countries at the global level is perhaps not sufficient to encounter all the transmission mechanisms occurring after a crisis. The growing literature about contagion (Favero and Giavazzi, 2002, Forbes and Rigobon, 2002) has shown that the correlation between markets is rising with the diffusion of crisis shocks. Blatt and others (2015) recently show that there is a delay between the occurrence of a crisis (detected by a higher volatility) and the contamination of the other markets (detected by the increase in correlation).

Following Anselin (1999) we introduce diffusion processes via $W \cdot g_{t-1}$ where $W$ is a $n \times n$ matrix representing the distance between country $i$ and $j, i \times j \in n \times n$. In such a case, it is straightforward to notice that a decrease by $1 \%$ in output in country $i$ at time $t-1$ will impact country $j$ at time $t$ by $W_{i, j} \%$. It has to be noticed that these weights are fixed over times and that the matrix $W$ is not unique: most of the time it is a geographical distance but it can also be a measure of trade integration, financial flows, industrial proximity, etc. In this paper, the weights are extracted from second generation GeoDist dataset from CEPII. 
Table 4: New Normals Testing including Spatial Diffusion terms

\begin{tabular}{l||rr|rr}
\hline \hline & $\begin{array}{r}1960 \\
\text { coêffs }\end{array}$ & $\begin{array}{r}-2001 \\
\text { se }\end{array}$ & $\begin{array}{r}1960 \\
\text { coêffs }\end{array}$ & $\begin{array}{r}-2010 \\
\text { se }\end{array}$ \\
\hline \hline$g_{-1}$ & 0.274 & $0.015^{* * *}$ & 0.286 & $0.013^{* * *}$ \\
$W_{n} g_{-1}$ & -0.010 & 0.028 & -0.015 & 0.025 \\
BAN(-1) & -0.552 & 0.340 & -0.754 & $0.297^{* * *}$ \\
CUR(-1) & -0.475 & 0.347 & -0.670 & $0.305^{* * *}$ \\
$\operatorname{DOM}(-1)$ & -0.823 & 0.791 & -0.142 & 0.672 \\
$\operatorname{EXT}(-1)$ & -0.357 & 0.369 & -0.275 & 0.326 \\
$\operatorname{IND}(-1)$ & 1.058 & 1.521 & 1.107 & 1.438 \\
$\operatorname{INF}(-1)$ & -0.108 & 0.387 & -0.140 & 0.342 \\
$\operatorname{STO}(-1)$ & -1.532 & $0.306^{* * *}$ & -1.605 & $0.267^{* * *}$ \\
\hline \hline
\end{tabular}

Notes: This table reports the results of the estimations of model (3) including fixed country effect and using Maximum Likelihood methods. Standard errors are reported after a White correction. *** indicates significant estimators at $1 \%, * *$ at $5 \%, *$ at $10 \%$.

This dataset contains rich geographical information, in particular, dyadic data which allows us to pinpoint distances between a given country and every other country in the world. The geodesic distances are calculated based on the geographic coordinates of the most important city in each economy (in terms of population). Therefore the model becomes:

$$
g_{n t}=\lambda_{0} W_{i} g_{n t}+\gamma_{0} g_{n, t-1}+\rho_{0} W_{n} g_{n, t-1}+X_{n t} \beta_{0}+\mathbf{c}_{i 0}+\alpha_{t 0} l_{n}+V_{n t}, \quad t=1,2, \ldots, T,
$$

where $g_{n t}=\left(g_{1 t}, g_{2 t}, \ldots, g_{n t}\right)^{\prime}$ and $V_{n t}=\left(v_{1 t}, v_{2 t}, \ldots, v_{n t}\right)^{\prime}$ are $n \times 1$ column vectors and $v_{i t}$ is i.i.d. across $i$ and $t$ with zero mean and variance $\sigma_{0}^{2}$. Also, $W_{n}$ is an $n \times n$ spatial weights matrix which is nonstochastic and generates the spatial dependence among cross sectional units $g_{i t}, X_{n t}$ is an $n \times k_{x}$ matrix of nonstochastic regressors (output growth and lags of output growth and crises dummies respectively), $\mathbf{c}_{n 0}$ is $n \times 1$ column vector of individual fixed effects, $\alpha_{t 0}$ is a scalar of time effect and $l_{n}$ is $n \times 1$ column vector of ones. $W_{n}$ is usually row normalized from a symmetric matrix, which ensures that all the weights are between 0 and 1 and weighting operations can be interpreted as an average of the neighboring values.

The spatial dynamic panel (3) is estimated using maximum likelihood. ${ }^{8}$ As in the previous sections, the test for the new normal hypothesis is done via a significance test of the crises dummy variables. Estimation results are reported in Table (4).

It first appears that the coefficient $W_{n} g_{-1}$ associated with the spatial dependence across units is not significantly different from zero, suggesting the absence of crisis diffusion across regions. This result confirm the results of recent papers by Rose and Spiegel (2010) and (2011), which reject the presence of contagion by using a cross-sectional econometric method.

\footnotetext{
${ }^{8}$ We thanks Nicolas Debarsy for providing his estimation codes.
} 
The yearly frequency may be at the origin of such a result: the transmission period of a crisis across regions could be shorter than a year (especially in a globalized world where financial markets are interrelated), and therefore it might be impossible to detect it using low frequency data. Another explanation could be that the matrix $W$ which is an aggregate measure of the potential channel would dampen the effect of a dominating channel of contagion as trade, finance, etc.

The other estimated coefficients confirm the findings obtained in the previous sections. Support for the "new normal" is strong once we include the recent financial turmoil. Only the stock market crisis coefficient remains significant in the sample ending in 2001. In the extended sample the banking, currency and the stock market crises have a negative impact on output growth, at 1 percent significance.

\section{Testing for "new normal": A historical analysis}

Until now we found clear evidence of a "new normal" once we controlled for globalization, in the sample ending in 2010. That was not necessarily the case in the sample ending in 2001, as only stock market crises subtracted significantly from growth, but not banking and currency crises (at significance lower than 10 percent). Therefore we are interested to refine our results, and investigate how robust are our results for various sample lengths.

To analyze the stability of the "new normal" hypothesis, models (1) and (2) are estimated recursively for the samples $1960-i$ with $i=1980,1985,1990,1995,2000$ and 2005 . We chose these intervals for two reasons. First, the eighties and the nineties are known for financial liberalization and financial integration (Kose and others, 2009, Oulton and Barriel ,2013, Rousseau and Wachtel, 2011). Second, we note that once we introduce the principal components the banking crisis dummy is significant only in the sample ending 2010. By testing the hypothesis in a sample ending in 2005 it would be clear if we confirm fully the "new normal" hypothesis as defined by El-Erian and PIMCO. Table 5 reports the estimated coefficients for the crisis dummies variables only. ${ }^{9}$

The results gathered in the lower part of Table 5 (corresponding to model (2) including the principal component terms) confirm that the significance of the banking and currency crisis dummies is indeed a recent phenomenon. The currency crisis dummy begins to be significant and negatively impacting the real output growth only with the sample finishing in 2005 (and at 10 percent level with the sample ending in 2000). The Argentine peso crisis as well as the recent collapse of the $\mathrm{BRICS}^{10}$ currencies are most likely at the origin of this

\footnotetext{
${ }^{9}$ The other coefficients are not reported for the sake of space but can be obtained from the authors upon request. Since tables 1 and 3 already report the estimated coefficients for the full sample, 1960 - 2010, those coefficients are also not incorporated here, to save space.

${ }^{10}$ Brazil, Russia, India, China and South Africa.
} 
Table 5: Temporal Stability Analysis

\begin{tabular}{|c|c|c|c|c|c|c|}
\hline & \multicolumn{6}{|c|}{ Model (1) without Principal Component terms } \\
\hline & -1980 & -1985 & -1990 & -1995 & -2000 & -2005 \\
\hline $\operatorname{BAN}(-1)$ & $-1.520^{*}$ & $-1.383^{* * *}$ & $-0.695^{* * *}$ & $-0.524^{* * *}$ & $-0.488^{* *}$ & $-0.489^{* *}$ \\
\hline CUR $(-1)$ & -0.446 & -0.560 & -0.279 & -0.303 & $-0.508 * *$ & $-0.521^{* *}$ \\
\hline $\operatorname{DOM}(-1)$ & -1.121 & $-2.422^{* * *}$ & -1.115 & -0.391 & -0.603 & -0.223 \\
\hline $\operatorname{EXT}(-1)$ & 0.224 & -0.504 & $-0.747 * *$ & -0.434 & -0.342 & -0.296 \\
\hline $\operatorname{IND}(-1)$ & -0.606 & -0.473 & -0.360 & -0.722 & -0.336 & -0.382 \\
\hline $\operatorname{INF}(-1)$ & -0.804 & $-0.877^{* *}$ & $-0.779 * * *$ & $-0.472^{* *}$ & -0.126 & $5.54 \mathrm{E}-06$ \\
\hline $\operatorname{STO}(-1)$ & $-2.037^{* * *}$ & $-1.793^{* * *}$ & $-1.640^{* * *}$ & $-1.665^{* * *}$ & $-1.589^{* * *}$ & $-1.632^{* * *}$ \\
\hline \multicolumn{7}{|c|}{ Model (2) with Principal Component terms } \\
\hline $\operatorname{BAN}(-1)$ & -1.659 & -0.835 & -0.166 & -0.040 & -0.179 & -0.249 \\
\hline CUR(-1) & 0.034 & -0.432 & -0.150 & -0.265 & $-0.474^{*}$ & $-0.510^{* *}$ \\
\hline $\operatorname{DOM}(-1)$ & -0.324 & $-1.927^{*}$ & -0.894 & -0.224 & -0.421 & -0.070 \\
\hline $\operatorname{EXT}(-1)$ & 0.221 & -0.406 & -0.440 & -0.135 & -0.120 & -0.136 \\
\hline $\operatorname{IND}(-1)$ & 0.349 & -0.461 & -0.336 & -0.642 & -0.262 & -0.304 \\
\hline $\operatorname{INF}(-1)$ & -0.366 & -0.586 & $-0.521^{*}$ & -0.196 & 0.033 & 0.086 \\
\hline $\operatorname{STO}(-1)$ & $-1.479 * * *$ & $-1.64^{* * *}$ & $-1.620 * * *$ & $-1.629^{* * *}$ & $-1.575^{* * *}$ & $-1.593^{* * *}$ \\
\hline
\end{tabular}

Notes: This table reports the results of the estimations of models (1) and (2) for different subsample periods beginning in 1960. Estimations include one lag, fixed country effect and Maximum Likelihood methods. Standard errors are reported after a White correction. *** indicates significant estimators at $1 \%, * *$ at $5 \%, *$ at $10 \%$. 
result. The real impact of the banking crisis is even more recent and it is driven by the last sample observations, as the associated dummies turn out not to be significantly different from zero for the samples ending in 2005, but it was significant in the whole sample (ending in 2010), as presented in Table 3. Such a result is unambiguously the consequence of the 2008 great financial crisis, and therefore fully confirming the "new normal" hypothesis as defined by El-Erian and PIMCO.

The comparison of these results with those reported in the upper part of Table 5 (model (1) estimated without the principal component terms) is also informative. Omitting PC1, the banking crisis dummy becomes significant from 1985 at 1 percent. Interpreting this result as the permanent impact of banking crises on real activity would be incorrect. It simply reveals that financial/banking globalization (proxied by PC1) which has started sometimes between 1980 and 1985 has on average fostered output growth. There is not yet a "new normal", but solely higher interdependence between countries.

Our historical analysis confirms the following results: (1) the "new normal" clearly is a stylized fact characterizing the new millennium,(2) international financial integration benefitted output growth, but it started to subtract from growth after 2005, due to the cost of banking and currency crises $^{11}$, (3) omitting to control for the positive effects of globalization in the long run it would have overestimated the negative impact of crises, especially of banking crises. $^{12}$.

These nuanced conclusions are consistent with Philippon and Reshef (2013) which note that after the 1980s income grows more slowly relative with credit and with Oulton and Barriel (2013) that found that banking crises on average have a substantial and statistical significant negative effect on short-run growth rate and long run level of labor productivity (and therefore output). Only banking crises have these negative effects, and more importantly, banking crises are mostly concentrated after 1980s. Appendix 2 shows that in our sample, out of ninety two episodes of banking crises, indeed only five banking crises originated prior to 1980 .

\footnotetext{
${ }^{11}$ The currency crises only affected negatively growth after 2000.

${ }^{12}$ It is important to note also that the stock market dummy is constantly and significantly impacting the real economy throughout all samples. Once we control for globalization those coefficients are lower, as well as the ones for domestic debt crisis and inflation, but for the latter only for in samples ending in 1985, and $1990 s$ respectively. The external crisis dummy is significant only in the specification without principal components, in the sample ending in 1990
} 


\section{Testing for "new normal": an income level perspec- tive}

It is important to study the results' robustness also according to the income level. Previous papers have already documented the variety of magnitudes of the negative impact of crises on output growth according to income groups (CS, etc). However, we do so now with a longer sample and while controlling for globalization. We also documented that overall financial integration benefited output growth on average, but it started to negatively impact output growth in the new millennium due to the cost of banking and currency crises. Therefore, it remains to confirm the missing piece. Is the "new normal" really a worldwide phenomenon, or restricted only to those countries that have benefited over the long run the most from financial development and integration?

In particular, we want to see for which set of countries the previous results hold. To this aim, models (1) and (2) will be estimated considering the income classification proposed by the World Bank. ${ }^{13}$ As CS, we create 5 clusters among our countries: the low income (Gross national income per capita below 1, $045 U S D$ ), the low middle income (GNI per capita below 4, $125 U S D$ ), the upper middle income (GNI per capita below 12,746USD), and the high income member of the OECD or not (GNI per capita above 12,746 USD). Models (1) and (2) are estimated over the full sample 1960 - 2010 for these five clusters. As before, to save space, Table 6 reports only the estimated coefficients obtained for the crisis dummies variables. The rest of results are available of the authors upon request.

Crisis dummies have different impact on output growth given the income cluster they are belonging to. Crises have thus a heterogenous impact across different income levels and the "new normal" cannot be accepted or rejected for the whole sample of countries. The most affected countries seem to be the high income OECD countries and the upper middle countries. We will start the exposition of our results with those groups.

Consistent with Wilms, Swank and de Haan (2014) we find that countries with higher GDP per capita have more severe activity downfalls after banking crises. Table 6 reports an output growth fall of about -0.91 in the aftermath of a banking crisis for high income OECD countries, and slightly lower if the principal component terms are included. As Appendix 1 shows, these high income OECD countries are primarily European countries, in which the banking sector has sorely developed during the last 20 years. In those countries the financial sector played a major role in the real economic growth ${ }^{14}$ and constitutes now a potential risk for these economies. The "new normal" is a post-2008 phenomenon, as the results in

\footnotetext{
${ }^{13}$ See http://data.worldbank.org/about/country-and-lending-groups for the description of the classification and the list of countries.

${ }^{14}$ Real estate mortgages and pension funds constitute a large part of household liabilities which transit via the banking sector.
} 
Table 6: New normal hypothesis and income levels

\begin{tabular}{rrrrrr}
\hline \hline & \multicolumn{5}{c}{ Model (1) without Principal component terms } \\
& Low Income & Low Middle & upper middle & High OECD & High non-OECD \\
\hline BAN(-1) & -0.319 & -0.226 & -0.652 & $-0.912^{* * *}$ & -1.586 \\
CUR(-1) & 0.083 & 0.037 & $-1.355^{* * *}$ & -0.371 & -0.895 \\
DOM(-1) & $-2.570^{* * *}$ & -1.111 & 0.713 & - & - \\
EXT(-1) & 0.483 & -0.611 & $-1.043^{* * *}$ & 2.2086 & $1.614^{* * *}$ \\
IND(-1) & -1.620 & -0.013 & - & - & - \\
INF(-1) & -0.145 & -0.310 & 0.301 & 0.508 & 1.436 \\
STO(-1) & $-3.577^{* * *}$ & 0.203 & $-2.210^{* * *}$ & $-1.765^{* * *}$ & $-2.333^{* * *}$ \\
& & & & & \\
\hline & & Model $(2)$ with Principal component terms & -1.477 \\
\hline & & & & & -0.822 \\
BAN(-1) & -0.470 & 0.101 & -0.372 & $-0.866^{*}$ & - \\
CUR(-1) & 0.028 & -0.110 & $-1.298^{* * *}$ & -0.413 & - \\
DOM(-1) & -2.617 & -1.055 & 0.925 & $-1.876^{* * *}$ \\
EXT(-1) & -0.428 & -0.603 & $-1.124^{* *}$ & 2.026 & - \\
IND(-1) & -1.418 & 0.234 & - & - & 1.575 \\
INF(-1) & -0.019 & -0.332 & 0.167 & 0.340 & $-2.877^{* * *}$ \\
STO(-1) & $-3.797^{* * *}$ & -0.096 & $-2.480^{* * *}$ & $-1.757^{* * *}$ & \\
\hline \hline
\end{tabular}

Notes: This table reports the results of the estimations of models (1) and (2) for the different group of countries as defined by the World Bank according to their income per capita. Estimation period covers the period $1960-2010$. Models include one lag, fixed country effect and are estimated using Maximum Likelihood methods. Standard errors are reported after a White correction. *** indicates significant estimators at $1 \%, * *$ at $5 \%, *$ at $10 \%$. - - indicates that no crisis is encountered for a particular cluster. 
Table 7 show that for these countries neither the banking nor the crisis dummy coefficient are significant in the sample ending in 2001 (with or without principal components). Therefore, since the high income OECD countries have the most developed financial systems, the expected lower output growth post 2008 crisis is due to the banking crises cleanup. This is a result consistent with Sahay and others (2015), Aizenman and others (2015) and Rousseau and Wachtel (2011) that as the financial sector develops it has diminishing marginal impact, and even negative, on real output growth. This result is particularly in line with how ElErian and PIMCO (2009) defined the "new normal": a longer than usual recovery following the 2008 global financial crisis (and hence lower output growth), particularly in advanced economies, as those economies needed to deleverage more.

Besides the importance of the banking crisis, we notice that stock market crashes also impact activity in this group of high income OECD countries, where agents hold the highest share of their income in stock exchange markets. In addition, in figure $2 \mathrm{a}$ and $\mathrm{b}$ in the Appendix we reported the estimators of the fixed effects. They turn out to be very small except for one country, Korea, for which a positive fixed effect is detected. The result is not surprising, because although Korea have been negatively impacted by crises, especially the 1998 banking crisis, it also grew on average much more over the sample, and even post2008 than the rest of OECD high income countries. ${ }^{15}$ This implies that on average Korea benefitted from financial globalization, and it still has room to grow, as long as country specific imbalances do not develop.

Table 6 also shows that upper middle countries are also affected negatively by crises in the sample ending in 2010. The coefficient of currency, external and stock market crises are negative, and significant. Moreover, once we control for globalization the coefficient on currency crises is lower. ${ }^{16}$ Indeed, several of these countries (Argentina, Brazil, Turkey, to name but a few) have experienced periods during which their foreign reserves have been exhausted ${ }^{17}$ or have had bouts of high loss in the currency value, especially in the past two decades. The external debt default or restructuring has negatively affected the growth for this group of countries.

The "new normal" hypothesis of lower GDP growth rate is also supported for high income countries not belonging to the OECD. For these countries, output growth is not affected by banking and currency crises, but by stock market crises, regardless of the specification used. Upon a closer inspection of Appendices 1 and 2, one finds that this is not a surprising result, as out of eleven countries, only two have consistently recorded crises: Singapore and Uruguay.

\footnotetext{
${ }^{15} \mathrm{By} 7.4 \%$ on average, when the other high income OECD countries grew by $3.3 \%$ over the sample, and by $3.2 \%$, when the other high income OECD countries stagnated on average post 2008 respectively.

${ }^{16}$ Interestingly though, the coefficients for stock market crisis and external debt are higher once we control for globalization, although the latter is significant only starting with 5 percent.

${ }^{17}$ See Flood and Garber (1984) characterize a currency crisis at the date when foreign reserves are zero.
} 
Table 7: New normal testing for high OECD countries until 2001

\begin{tabular}{rrr}
\hline \hline & without PC & with PC \\
\hline BAN(-1) & -0.500 & 0.133 \\
CUR(-1) & -0.321 & -0.151 \\
$\operatorname{EXT}(-1)$ & 1.960 & 2.143 \\
$\operatorname{INF}(-1)$ & 0.121 & -0.006 \\
STO(-1) & $-1.750^{* * *}$ & $-1.778^{* * *}$ \\
\hline \hline
\end{tabular}

Notes: This table reports the results of the estimations of models (1) and (2) for high OECD countries until 2001. Estimations include one lag, fixed country effect and using Maximum Likelihood methods. Standard errors are reported after a White correction. *** indicates significant estimators at $1 \%, * *$ at $5 \%, *$ at $10 \%$.

Moreover, those countries recorded crises mostly prior to mid 1990s, and none of them had a banking crisis post-2008. This finding would suggest that in front of a certain type of crisis authorities should not necessarily implement new structural policies but accommodate the shock in the short run, should there be policy space for maneuver. ${ }^{18}$

Low income countries' real output growth is slightly affected by domestic debt crises, although this result does no longer hold once we control for globalization. These countries are affected by stock market crashes, and the negative impact on real GDP growth increases once we control for globalization. This latter result might be surprising, as those countries have the least developed capital markets. However, upon a closer inspection of Appendix 2 we see that only two countries in this group have experienced stock market crises: Kenya and Zimbabwe. Moreover, several studies (Nissanke, 2009 inter alia) have highlighted the link between stock market crashes and the collapse of oil and non-oil raw commodities prices. As output growth in low income countries is linked to the fate of natural resource prices in the global markets, this result is no longer surprising.

The output growth of low middle income countries seems not to be affected by crises over the long run, and therefore there is no evidence for a "new normal" in this group. While those countries have also seen their share of crises, they seem to rebound relatively quickly, and therefore can still benefit from financial development and financial integration, if proper policies are in place.

Low income, low middle income, and high income non-OECD countries still have room to benefit from the development and integration of their financial systems. However, for them, and in particular for the upper middle and high income OECD countries better (not necessarily more) banking regulation and supervision, and more broadly better financial regulation and supervision is required. Upper middle countries need to pay particular attention to signs of vulnerability in their economy and the stance of their macroeconomic policies and the stability of their political system, as they are the most prone to be negatively impacted

\footnotetext{
${ }^{18}$ Hutchsion and others (2010) that countries faced with a sudden stop have the lowest output fall if the monetary policy is neutral, and the fiscal policy is expansionary.
} 
Table 8: Temporal Stability Analysis

\begin{tabular}{lrrrrrrr}
\hline \hline \multicolumn{7}{c}{ Model (1) without Principal Component terms } \\
& -1980 & -1985 & -1990 & -1995 & -2000 & -2005 & -2010 \\
\hline BAN(-1) & -1.072 & $-1.822^{* * *}$ & -0.792 & $-1.237^{* * *}$ & $-1.254^{* * *}$ & $-1.099^{* * *}$ & $-1.369^{* * *}$ \\
CUR(-1) & -0.544 & $-0.704^{*}$ & -0.488 & $-0.462^{* * *}$ & $-0.665^{* * *}$ & $-0.654^{* * *}$ & $-0.754^{* * *}$ \\
\multicolumn{7}{c}{} \\
\hline \multicolumn{7}{c}{ Model (2) with Principal Component terms } \\
\hline BAN(-1) & -0.873 & -1.271 & -0.349 & -0.843 & $-1.041^{* * *}$ & $-0.948^{*}$ & $-1.280^{* * *}$ \\
CUR(-1) & 0.544 & -0.555 & -0.314 & -0.383 & $-0.602^{* *}$ & $-0.622^{* * *}$ & $-0.763^{* * *}$ \\
\hline \hline
\end{tabular}

Notes: This table reports the results of the estimations of models (1) and (2) for different subsample periods beginning in 1960 and using LV banking crises dummies. Estimations include one lag, fixed country effect and using Maximum Likelihood methods. Standard errors are reported after a White correction. ${ }^{* * *}$ indicates significant estimators at $1 \%,{ }^{* *}$ at $5 \%,{ }^{*}$ at $10 \%$.

by currency crises. As the upper middle income countries tend to have open and relatively deep markets when the global capital is abundant and searching for yield, they will be particularly affected if their business cycles are not perfectly synchronized with the ones in high income countries. As Cecchetti (2012) notes, globalization is good, but not always.

\section{Robustness Checks}

To assess the robustness of our results, we consider an alternative crisis detection methodology and the most recent observations. Several data bases are available. We choose the one proposed by Leaven and Valencia (2013) (hereafter LV) as it is also widely accepted among scholars. It differs from the one developed by Reinhart and Rogoff in several aspects. First LV consider different criteria and threshold to define their crisis sequence. Second, LV only defines four different types of crises: the banking, the currency, and the sovereign debt crisis (separating the date of default and the year of restructuration). Besides, the banking crisis considered in LV is the systemic banking crisis, which is only a subset of banking crises encountered in the country (the most sever one).

In a first robustness check exercise, we replace the dummy crises with the ones from LV, in the sample ending in 2010. A simple correlation analysis reveals that this banking crisis dummy is relatively highly correlated with the Reinhart and Rogoff (2009) previously used (41\%). We expect therefore that our results should not be dramatically modified using the LV banking crisis dummy. Still we perform the temporal stability exercise as in Section 4 using LV banking dummy. Table 8 reports the estimation results.

We first observe that banking crises have a negative effect on output growth. This impact is larger than estimated in the sections 2-4, as the coefficients associated with the banking crisis turn out to be higher than those reported in Table 5. Such a finding can 
Table 9: New Normals Testing for high income OECD countries until 2014

\begin{tabular}{l||rr|rr}
\hline \hline \multicolumn{1}{l||}{} & \multicolumn{2}{c}{ without PC terms } & \multicolumn{2}{c}{ with PC terms } \\
& coeffs & se & coeffs & se \\
\hline \hline$g_{-1}$ & 0.359 & $0.627^{* * *}$ & 0.286 & $0.050^{* * *}$ \\
$g_{-2}$ & -0.066 & 0.043 & -0.079 & 0.040 \\
$g_{-3}$ & 0.138 & $0.014^{* *}$ & 0.133 & $0.042^{* *}$ \\
$g_{-4}$ & -0.022 & 0.032 & -0.030 & 0.033 \\
$P C_{-1}$ & & & 7.027 & 4.759 \\
$\operatorname{BAN}(-1)$ & -1.818 & $0.709^{* * *}$ & -1.546 & $0.660^{* * *}$ \\
$\mathrm{CUR}(-1)$ & -0.344 & 0.442 & -0.324 & 0.429 \\
$\operatorname{INF}(-1)$ & -0.294 & 0.609 & 0.134 & 0.617 \\
$c$ & 2.085 & $0.609^{* * *}$ & 1.584 & $0.515^{* * *}$ \\
\hline \hline
\end{tabular}

Notes: This table reports the results of the estimations of model (3) including fixed country effect and using Maximum Likelihood methods. Standard errors are reported after a White correction. *** indicates significant estimators at $1 \%, * *$ at $5 \%, *$ at $10 \%$.

be explained by the systemic characteristics of the LV banking crisis. A systemic banking crisis is expected to have a higher impact on output growth than a non systemic one. ${ }^{19}$ The overall picture remains similar to the one we previously found with the Reinhart and Rogoff (2009) database: the impact of crises, and particularly of banking crises, is becoming more significant since 2000, once we account for globalization.

The second robustness check consists in extending the analysis for the most recent periods, i.e. 2014. This exercise is not easy to do. First, because the output growth data gets to be revised, usually up to two years after its publication (on average). Second, crises dummies produced by Leaven and Valencia (2013) or Reinhart and Rogoff (2011) end respectively in 2012 and 2010. We thus decided to extend the LV banking and currency crises dummy until $2014^{20}$ only in the case of high income OECD countries, for which we expect only slight modification in the output growth statistics. We also add an inflation crisis dummy. A new principal component analysis is performed and it appears that the first one explained around $73 \%$ of the volatility whereas the next ones explained less than $5 \%$. We report the regression including a single principal component and report the results in Table 9.

Again the findings of this robustness check is similar to the one we obtained in Section 5. The banking crises have a significant negative impact on the output growth rate of high income OECD countries, whereas currency crises do not have any effect. Again, we notice that the estimated coefficients of the banking crises dummies are higher than the one obtained with Reinhart and Rogoff data. ${ }^{21}$

\footnotetext{
${ }^{19}$ The difference in crisis databases explains also the difference in the impact on GDP level (impulse response functions) we obtain compared to CS or Hutchison and Noy (2005).

${ }^{20}$ We thank Fabian Valencia for advising us how to do so.

${ }^{21}$ Similarly, the impact of a twin crisis can be calculated as the sum of the coefficients of the banking and the currency crises as both are only weakly correlated. It turns out to be quite high $(>2)$.
} 
This robustness section clearly corroborates thus the findings of the previous sections. Comparing the results of Tables 8 and 9, we see that the negative impact of banking crises on GDP growth is higher for high income OECD countries, for a sample ending in 2014 than for all countries for the sample ending in 2010, clearly supporting the "new normal" hypothesis as defined by El-Erian and PIMCO (2009).

\section{Conclusion}

The interest in empirical evidence in a "new normal" exists not only because seven years after the global financial crisis of 2008 the prospects of growth remain relatively weak and uneven across regions and income levels, but also for policy debate and the construct of theoretical models. Knowing for sure that there is a "new normal", would imply that after each recession, especially the ones following a crisis, the recommended policies would not only be stabilization policies but also strong structural reforms, such that over the long run the effects of the negative short run developments would be mitigated. Moreover, a new generation of theoretical models would be needed, because in the presence of a new stationary equilibrium after the occurrence of a crisis, models assuming a deterministic steady-state (like most of the DSGE models do) and log-linearization around this long run equilibrium would be unable to capture well the impact of the crisis.

This paper extended the Cerra and Saxena (2008) framework in a systematic way, to corroborate evidence of a "new normal" by refining the estimation of the impact of crises on output growth. Cerra and Saxena (2008), using data from 1960 until 2001, from an unbalanced panel of 190 countries, debunked the myth of output recovering quickly from all recessions, especially after crises, and even slower after banking crises. We extended the sample to 2010, and we concentrated primarily on the role of economic crises, investigated the effect of more economic crises than in CS (stock market, debt, and inflation) on output growth, and, more importantly, we controlled for globalization and contagion effects.

For globalization we used a factor augmented panel and included spatial factors a la Anselin (1999), allowing for crisis diffusion strongly across countries in the short run. We investigated the effect of crises across various samples ending at different points in time, starting with 1980s because the evidence points to a concentration of banking crises after this date, and in our sample, out of ninety two episodes of banking crises, only five originated prior to 1980. As in Cerra and Saxena, we also investigated the impact of crises on output growth across various income levels, geographical areas, and using various crises databases. To avoid biases we use balanced panels with output growth rates and the crises dummies from Reinhart and Rogoff (2009) from 100 countries, for the period 1960-2010. For robustness we used the Laeven and Valencia (2013) crises database and undertook the analysis for high 
income OECD countries with data until 2014.

The paper finds unambiguously that crises affect negatively output growth. When we regress real GDP growth on its own lags, and a set of individual country specific dummies, we find that the coefficients of the crises dummies are negative, and tend to be consistently significant. Moreover, the paper corroborates evidence of a "new normal", by finding that the negative effects of the currency, banking and stock market crises are stronger and higher when including data from the 2008 crisis. Although banking crises have a negative significant effect starting with 1980, especially for high-income OECD countries, once we control for globalization the banking crisis is significant only in the post-2008 sample. While currency crises also have a negative effect on output growth, they are significant only with 2000 (including when we control for globalization), especially for upper middle income countries. Stock market crises have a significant negative effect on output growth, regardless of the time period considered, and even when we control for globalization and contagion.

We controlled for globalization, by factor augmenting the panel. To do so we extracted first the principal component in output growth across countries. As we find a principal component that is negatively correlated with the banking, currency crises, external debt default, and inflation, and that component has a positive impact on output growth on average over the sample, we interpret this to be the role of globalization, especially financial integration and liberalization. Moreover, once we incorporate this component in our output growth regressions we find that banking crisis have a negative effect on output growth, only in the extended sample, and, more importantly, mostly for high income OECD countries. These results not only support the "new normal" hypothesis as stated by El-Erian and PIMCO in 2009, but also Cecchetti's 2012 tentative conclusion that globalization is good, but not always. In addition, as this component's positive impact on growth on average is lower in the sample ending in 2010 than in the one ending in 2001, the results imply like in Aizenman and others (2015), Sahay and others (2015), and Rousseau and Wachtel (2011) that there is a non-linear relationship of finance and growth, where the development of financial sector benefits the real sector up to a point, because thereafter there are diminishing marginal returns to financial development due to the costs of cleaning up banking crises. The results remain robust once we use other crises dummy variables, a la Laeven and Valencia (2013), and even more recent data, where available (until 2014, for high income OECD countries).

Hence the paper's contribution to literature is trifold. First, it presents unambiguous, systematic and comprehensive evidence of a "new normal", as stated by El-Erian and PIMCO (2009): lower output growth is the new norm, especially in advanced economies where consumers needed to deleverage extensively for a lot longer than what would have been expected in an usual cyclical recovery. That will continue, unless as Obstfeld (2011) noted, the existing informational and institutional structure for global policymaking improves. Second, 
by factor augmenting the panel we show a new, more refined way to estimate the impact of crises on output growth. Third, this method allows not only to show evidence for threshold effects for the finance impact on real output growth, and of financial integration impact on growth, but to the best of our knowledge, for the first time it links both these results, and therefore types of literature. 


\section{References}

Aizenman, Joshua, Yothin Jinjarak and Donghyung Park, 2015. "Financial Development and Output Growth in developing Asia and Latin America: A Comparative Sectoral Analysis", National Bureau of economic research Working Paper No. 20917, January.

Anselin, Luc, 1999. "Spatial Econometrics" Mimeo University of Texas at Dallas, http : //www.csiss.org/learning $g_{r}$ esources/content/papers/baltchap.pdf.

Bai, Jushuan 2009. "Panel Data Models with Interactive Fixed Effects," Econometrica 77(4), 1229-1279.

Blatt, Dominik, Candelon, Bertrand and Hans Manner 2015. "Detecting contagion in a multivariate time series system: An application to sovereign bonds markets in Europe" Journal of Banking and Finance, vol.59, 1-13.

Bordo, Michael, Barry Eichengreen, Daniela Klingebiel and Maria Soledad Martinez-Peria, 2001. "Is the crisis problem growing more severe?," Economic Policy, CEPR;CES;MSH, vol. 16(32), pages 51-82, 04 .

Cerra, Valerie and Sweta Chaman Saxena, 2008. "Growth Dynamics: The Myth of Economic Recovery," American Economic Review, American Economic Association, vol. 98(1), 439-57, March.

Cecchetti, Stephen, 2012. "Is Globalization Great?", Bank of International Settlements papers No. 69. Pp 1-6.

Favero, Carlo A. and Francesco Giavazzi 2002. "Is the international propagation of financial shocks non-linear?: Evidence from the ERM," Journal of International Economics, Elsevier, vol. 57(1), pages 231-246, June.

Flood, Robert and Peter Garber, 1984, "Collapsing Exchange-Rate Regimes: Some Linear Examples," Journal of International Economics Vol. 17, pp. 1-13.

Forbes, Kristin J. and Roberto Rigobon, 2002. "No Contagion, Only Interdependence: Measuring Stock Market Comovements," Journal of Finance, American Finance Association, vol. 57(5), pages 2223-2261, October. 
Glick, Reuven and Michael Hutchinson, 2000. "Banking and Currency Crises: How Common Are The Twins?," Working Papers 012000, Hong Kong Institute for Monetary Research.

Glick, Reuven and Andrew K. Rose, 1999. "Contagion and trade: Why are currency crises regional?," Journal of International Money and Finance, Elsevier, vol. 18(4), pages 603-617, August.

Hutchison, Michael M., Ilan Noy, and Lidan Wang, 2010. "Fiscal and Monetary Policies and the Cost of Sudden Stops", Journal of International Money and Finance, 29, pp. 973-987.

Hutchison, Michael M. and Ilan Noy, 2005. "How Bad Are Twins? Output Costs of Currency and Banking Crises", Journal of Money, credit and banking, 37(4), pp.725-752.

Im, Kyung So, Pesaran, M. Hashem and Shin, Yongcheol, 2003. "Testing for Unit Roots in Heterogeneous Panels", Journal of Econometrics 115, pp. 53-74

International Monetary Fund, 2015. World Economic Outlook: "Uneven Growth: Shortand Long-Term Factors", April.

International Monetary Fund, 2009. World Economic Outlook: "Sustaining the Recovery ", October, Chapter 4: What's the Damamge? Medium-Term Output Dynamics After Financial Crises", pp. 121-153.

Kose, Ayhan M., Eswar Prasad, Kenneth Rogoff and Shang-Jin Wei, 2009. "Financial Globalization: A Reappraisal," IMF Staff Papers, Vol. 56 No. 1, pp. 8-62.

Lagarde, Christine, 2015. "Lift Growth Today, Tomorrow, Together", Managing Director International Monetary Fund speech at the Atlantic Council, April 9.

Laeven, Luc and Fabian Valencia, 2013. "Systemic Banking Crises Database," IMF Economic Review, Palgrave Macmillan, vol. 61(2), pages 225-270.

Lee, Lung-Fei and Jihai Yu, 2010. "A spatial dynamic panel data model with both time and fixed effects", Econometric Theory 26, 564-597.

Levin, Andrew, Lin Chien-Fu, Chu Chia-Shang, 2002. "Unit root tests in panel data: asymptotic and finite sample properties" Journal of Econometrics 108, 1-24. 
Nissanke, Machiko 2009. "The Global Financial Crisis and the Developing World: Transmission Channels and Fall-outs for Industrial Development", Research and Statistics branch Working Paper 06/2009, United Nation Industrial Development Organization.

Obstfeld, Maurice, 2011. "Financial flows, financial crises, and global imbalances," Keynote Address to the 15th International Conference on Macroeconomic Analysis and International Finance, University of Crete, Greece, May, also Center for Economic Policy Research Discussion paper series no. 8611 .

Obstfeld, Maurice and Alan M. Taylor, 2004. "Global Capital Markets: Integration, Crises and Growth,", Cambridge University Press.

Oulton, Nicholas and Maria S. Barriel, 2013. "Long and Short Run Effects of the Financial Crisis on Labor Productivity, Capital and Output," Bank of England Working Paper no. 470, January.

Pesaran, Hashem, 2006. "Estimation and Inference in large Heterogeneous Panels with a Multifactor Error Structure", Econometrica 74, 967-1012. .

Philippon, Thomas and Ariel Reschef, 2013. "An international Look at Modern Finance," Journal of Economic Perspectives, Vol. 27 No. 2, Spring, pp. 73-96.

Reinhart, Carmen and Kenneth Rogoff, 2014. "Recovery from Financial Crises: Evidence from 100 Episodes," American Economic Review, May 2014.

Reinhart, Carmen and Kenneth Rogoff, 2011, "From Financial Crash to Debt Crisis," American Economic Review, Vol. 101, 5, pp. 1676- 706.

Reinhart, Carmen and Kenneth Rogoff, 2009. "This Time is Different: Eight centuries of Financial Folly," Princeton: Princeton University Press. data available at: http://www.reinhartandrogoff.con

Van Rijckeghem, Caroline and Beatrice Weder, 2003. "Spillovers through banking centers: a panel data analysis of bank flows," Journal of International Money and Finance, Elsevier, vol. 22(4), pages 483-509, August.

Van Rijckeghem, Caroline and Beatrice Weder, 2001. "Sources of contagion: is it finance or trade?," Journal of International Economics, Elsevier, vol. 54(2), pages 293-308, August. 
Rose, Andrew K. and Mark M. Spiegel, 2010. "Cross-Country Causes And Consequences Of The 2008 Crisis: International Linkages And American Exposure," Pacific Economic Review, Wiley Blackwell, vol. 15(3), pages 340-363, 08.

Rose, Andrew K. and Spiegel, Mark M., 2011. "Cross-country causes and consequences of the crisis: An update," European Economic Review, Elsevier, vol. 55(3), pages 309-324, April.

Rousseau, Peter L, and Paul Wachtel, 2011. "What is Hapenning to the Imapct of Financial Deepening on Economic Growth?", Economic Inquiry 49(1), pp.276-88 and Vanderbilt University deparment of Economics Working paper no. 09W-15.

Sahay, Ratna, Martin Cihak, Papa N'Diaye, Adolfo Barajas and others, 2015. "Rethinking Financial Deepening: Stability and Growth in Emerging Markets", IMF Discussion Note 15/08. .

Wilms, Philip, Job Swank, and Jakob de Haan, 2014. "Determinants of the Real Impact of Banking Crisis: A Review and new Evidence," De Netherlandsche Bank Working paper No. 437, August.

Yu, Jihai, Robert de Jong and Lung-Fei Lee, 2008. "Quasi-Maximum Likelihood Estimators for Spatial Dynamic Panel Data With Fixed Effects When Both n and T are Large," Journal of Econometrics 146, 118-134. 


\section{Appendix 1: List of countries}

\begin{tabular}{|c|c|c|}
\hline No. Country & Income Group & Region \\
\hline 1 Burundi & Low income & Africa \\
\hline 2 Benin & Low income & Africa \\
\hline 3 Burkina Faso & Low income & Africa \\
\hline 4 Central African Republic & Low income & Africa \\
\hline 5 Kenya & Low income & Africa \\
\hline 6 Liberia & Low income & Africa \\
\hline 7 Madagascar & Low income & Africa \\
\hline 8 Mali & Low income & Africa \\
\hline 9 Malawi & Low income & Africa \\
\hline 10 Niger & Low income & Africa \\
\hline 11 Rwanda & Low income & Africa \\
\hline 12 Sierra Leone & Low income & Africa \\
\hline 13 Chad & Low income & Africa \\
\hline 14 Togo & Low income & Africa \\
\hline 15 Congo, Dem. Rep. & Low income & Africa \\
\hline 16 Zimbabwe & Low income & Africa \\
\hline 17 Bangladesh & Low income & Asia \\
\hline 18 Myanmar & Low income & Asia \\
\hline $19 \mathrm{Nepal}$ & Low income & Asia \\
\hline 20 Côte d'Ivoire & Lower middle income & Africa \\
\hline 21 Cameroon & Lower middle income & Africa \\
\hline 22 Congo, Rep. & Lower middle income & Africa \\
\hline 23 Egypt, Arab Rep. & Lower middle income & Africa \\
\hline 24 Ghana & Lower middle income & Africa \\
\hline 25 Lesotho & Lower middle income & Africa \\
\hline 26 Morocco & Lower middle income & Africa \\
\hline 27 Mauritania & Lower middle income & Africa \\
\hline 28 Nigeria & Lower middle income & Africa \\
\hline 29 Sudan & Lower middle income & Africa \\
\hline 30 Senegal & Lower middle income & Africa \\
\hline 31 Zambia & Lower middle income & Africa \\
\hline 32 Indonesia & Lower middle income & Asia \\
\hline 33 India & Lower middle income & Asia \\
\hline 34 Sri Lanka & Lower middle income & Asia \\
\hline 35 Pakistan & Lower middle income & Asia \\
\hline 36 Philippines & Lower middle income & Asia \\
\hline 37 Bolivia & Lower middle income & Latin America \\
\hline 38 Guatemala & Lower middle income & Latin America \\
\hline 39 Guyana & Lower middle income & Latin America \\
\hline 40 Honduras & Lower middle income & Latin America \\
\hline 41 Nicaragua & Lower middle income & Latin America \\
\hline 42 Paraguay & Lower middle income & Latin America \\
\hline 43 Papua New Guinea & Lower middle income & \\
\hline 44 El Salvador & Lower middle income & \\
\hline 45 Syrian Arab Republic & Lower middle income & \\
\hline
\end{tabular}

\begin{tabular}{|c|c|c|}
\hline No. Country & Income Group & Region \\
\hline 46 Algeria & Upper middle income & Africa \\
\hline 47 Botswana & Upper middle income & Africa \\
\hline 48 Gabon & Upper middle income & Africa \\
\hline 49 South Africa & Upper middle income & Africa \\
\hline 50 Tunisia & Upper middle income & Africa \\
\hline 51 China & Upper middle income & Asia \\
\hline $52 \mathrm{Fiji}$ & Upper middle income & Asia \\
\hline 53 Malaysia & Upper middle income & Asia \\
\hline 54 Thailand & Upper middle income & Asia \\
\hline 55 Argentina & Upper middle income & Latin America \\
\hline 56 Brazil & Upper middle income & Latin America \\
\hline 57 Colombia & Upper middle income & Latin America \\
\hline 58 Costa Rica & Upper middle income & Latin America \\
\hline 59 Ecuador & Upper middle income & Latin America \\
\hline 60 Mexico & Upper middle income & Latin America \\
\hline 61 Panama & Upper middle income & Latin America \\
\hline 62 Peru & Upper middle income & Latin America \\
\hline 63 Belize & Upper middle income & \\
\hline 64 Dominican Republic & Upper middle income & \\
\hline 65 Seychelles & Upper middle income & \\
\hline 66 Turkey & Upper middle income & \\
\hline 67 St. Vincent and the Grenadines & Upper middle income & \\
\hline 68 Austria & High income: OECD & Europe \\
\hline 69 Belgium & High income: $\mathrm{OECD}$ & Europe \\
\hline 70 Denmark & High income: OECD & Europe \\
\hline 71 Spain & High income: OECD & Europe \\
\hline 72 Finland & High income: OECD & Europe \\
\hline 73 France & High income: OECD & Europe \\
\hline 74 Greece & High income: OECD & Europe \\
\hline 75 Italy & High income: OECD & Europe \\
\hline 76 Luxembourg & High income: OECD & Europe \\
\hline 77 Netherlands & High income: OECD & Europe \\
\hline 78 Portugal & High income: OECD & Europe \\
\hline 79 Sweden & High income: OECD & Europe \\
\hline 80 Japan & High income: OECD & Asia \\
\hline 81 Korea, Rep. & High income: OECD & Asia \\
\hline 82 Chile & High income: OECD & Latin America \\
\hline 83 Australia & High income: OECD & \\
\hline 84 Canada & High income: OECD & \\
\hline 85 United Kingdom & High income: OECD & \\
\hline 86 Iceland & High income: OECD & \\
\hline 87 Israel & High income: OECD & \\
\hline 88 Norway & High income: OECD & \\
\hline 89 United States & High income: OECD & \\
\hline 90 Hong Kong SAR, China & High income: nonOECD & Asia \\
\hline 91 Singapore & High income: nonOECD & Asia \\
\hline 92 Latvia & High income: nonOECD & Europe \\
\hline 93 Uruguay & High income: nonOECD & Latin America \\
\hline 94 Bahamas, The & High income: nonOECD & \\
\hline 95 Bermuda & High income: nonOECD & \\
\hline 96 Barbados & High income: nonOECD & \\
\hline 97 Kuwait & High income: nonOECD & \\
\hline 98 Oman & High income: nonOECD & \\
\hline 99 Puerto Rico & High income: nonOECD & \\
\hline 100 Trinidad and Tobago & High income: nonOECD & \\
\hline
\end{tabular}




\section{Appendix 2: Crises episodes}

\section{Appendix Table 2: Crises grouping by income level of countries and years 2/}

\begin{tabular}{|c|c|c|c|c|c|}
\hline Crisis & Low income & Lower middle income & Upper middle income & High OECD & High non-OECD \\
\hline \multirow[t]{20}{*}{ BAN } & $\begin{array}{l}\text { Central African Republic (1976-1982, 1988- } \\
\text { 1999) }\end{array}$ & Bolivia $(1986-1987,1994-1997,1999)$ & Algeria (1990-1992) & Australia (1989-1992) & Singapore (1990-1999) \\
\hline & Kenya (1985-1989, 1992-1995) & Egypt (1981-1983, 1990-1995) & $\begin{array}{l}\text { Argentina (1980-1982, 1989-1990, 1995- } \\
1996,2001-2003)\end{array}$ & Austria (2008-2010) & Uruguay $(1971,1981-1984,2002)$ \\
\hline & Myanmar (1996-2003) & El Salvador (1989) & Brazil $(1963,1985,1990,1994-1997)$ & Belgium (2008-2010) & \\
\hline & Zimbabwe (1995-2008) & Ghana $(1982-1989,1997)$ & China (1992-1999) & Canada (1983-1985) & \\
\hline & & Guatemala $(1990,2001,2006)$ & Colombia $(1982-1987,1998-1999)$ & Chile $(1976-1977,1982-1984)$ & \\
\hline & & Honduras $(1999,2001-2002)$ & Costa Rica $(1987,1994-1996)$ & Denmark (1987-1992, 2008-2010) & \\
\hline & & India (1993-1998) & Dominican Republic $(1996,2003)$ & Finland (1991-1994) & \\
\hline & & Indonesia $(1992,1994,1997-2002)$ & Ecuador $(1981,1998-2002)$ & France $(1994-1995,2008-2010)$ & \\
\hline & & Morocco (1983-1984) & Malaysia $(1985-1988,1997-2001)$ & Greece (1991-1995, 2008-2010) & \\
\hline & & Nicaragua (1987-1996, 2000-2002) & Mexico (1981-1982, 1994-2000) & Iceland $(1985-1986,1993,2007-2010)$ & \\
\hline & & Nigeria $(1992-1995,1997)$ & Panama (1988-1989) & Italy (1990-1995) & \\
\hline & & Paraguay (1995-1999, 2002) & Peru $(1983-1990,1999)$ & Japan (1992-2001) & \\
\hline & & Philippines (1983-1990, 1999) & South Africa $(1977-1978,1989)$ & Korea $(1983,1985-1988,1997-2002)$ & \\
\hline & & Sri Lanka (1989-1993) & Thailand (1980-1987, 1996-2001) & Netherlands (2008-2010) & \\
\hline & & Zambia (1995) & Tunisia (1991-1995) & Norway (1987-1993) & \\
\hline & & & Turkey $(1982-1985,1991,1994,2000)$ & Portugal (2008-2010) & \\
\hline & & & & Spain (1977-1985, 2008-2010) & \\
\hline & & & & Sweden (1991-1994) & \\
\hline & & & & $\begin{array}{l}\text { United Kingdom (1974-1976, 1984, 1991, } \\
\text { 1995, 2007-2009) }\end{array}$ & \\
\hline & & & & United States (1984-1991, 2007-2010) & \\
\hline \multirow[t]{17}{*}{ CUR } & Central African Republic (1994) & $\begin{array}{l}\text { Bolivia }(1963,1972,1979,1982-1985, \\
\text { 1987, 1989) }\end{array}$ & Algeria (1988-1991, 1994-1995) & $\begin{array}{l}\text { Australia }(1966,1976,1982,1985,1997, \\
2000,2008)\end{array}$ & $\begin{array}{l}\text { Singapore }(1973,1983,1990-2001,2008, \\
\text { 2010) }\end{array}$ \\
\hline & $\begin{array}{l}\text { Kenya }(1976,1981-1982,1989-1993,1999, \\
\text { 2008) }\end{array}$ & Egypt (1962, 1979, 1989-1991, 2001, 2003) & $\begin{array}{l}\text { Argentina }(1962,1964-1965,1967,1969- \\
1971,1974-1982,1984,1986-1992,2002)\end{array}$ & Austria (2005) & $\begin{array}{l}\text { Uruguay }(1963-1965,1967-1968,1970- \\
1972,1974,1976-1992,1994-1997,2001- \\
2002)\end{array}$ \\
\hline & Myanmar (1975) & El Salvador $(1973,1988)$ & $\begin{array}{l}\text { Brazil }(1961-1965,1968-1969,1971,1974- \\
\text { 1975, 1977-1985, 1987-1988, 1990-1992, } \\
\text { 1994-1995, 1999, 2001-2002, 2008) }\end{array}$ & Belgium $(1982,2005)$ & \\
\hline & $\begin{array}{l}\text { Zimbabwe (1977, 1982-1984, 1988-1991, } \\
\text { 1993-1994, 1996-1998, 2000, 2003-2008) }\end{array}$ & $\begin{array}{l}\text { Ghana }(1967,1971,1978,1983-1989,1992 \\
1997,1999-2000,2002,2008-2009)\end{array}$ & China $(1984,1986,1989,1994)$ & Canada (2008) & \\
\hline & & Guatemala $(1986,1989-1990)$ & $\begin{array}{l}\text { Colombia }(1962,1965,1967,1976,1980- \\
1991,1995,1997-2000,2002)\end{array}$ & $\begin{array}{l}\text { Chile }(1962-1965,1967,1969-1974,1976- \\
1979,1982-1985,1987,1989,2008)\end{array}$ & \\
\hline & & Honduras $(1990,1993-1994,1996)$ & Costa Rica $(1974,1981,1987,1991,1995)$ & Denmark (2010) & \\
\hline & & India $(1967,1984,1988,1991,1993,2008)$ & $\begin{array}{l}\text { Dominican Republic }(1985,1987-1988, \\
\text { 1990, 2002-2003) }\end{array}$ & Finland $(1963,1967,1992)$ & \\
\hline & & $\begin{array}{l}\text { Indonesia }(1962-1964,1966-1968,1978, \\
1983,1997-1998,2000,2008)\end{array}$ & Ecuador $(1971,1982-1992,1995-2000)$ & France $(1976,2005)$ & \\
\hline & & Morocco (1985) & Malaysia (1997) & $\begin{array}{l}\text { Greece }(1976,1980,1983,1985-1986, \\
1990,1999-2001,2005)\end{array}$ & \\
\hline & & Nicaragua $(1979,1985-1986,1991,1993)$ & $\begin{array}{l}\text { Mexico }(1976,1982-1987,1989,1994- \\
1995,1998,2008)\end{array}$ & $\begin{array}{l}\text { Iceland (1970, 1974-1986, 1988-1989, } \\
\text { 2008) }\end{array}$ & \\
\hline & & $\begin{array}{l}\text { Nigeria }(1973,1981,1985-1990,1992, \\
\text { 1999) }\end{array}$ & Peru $(1968,1976-1984,1987-1993,1998)$ & Italy $(1976,1992,2005)$ & \\
\hline & & $\begin{array}{l}\text { Paraguay (1984-1986, 1989, 1992-1993, } \\
\text { 1998-1999, 2001-2002) }\end{array}$ & $\begin{array}{l}\text { South Africa }(1981,1984-1985,1988,1996 \text {, } \\
1998,2000-2001,2008)\end{array}$ & Japan $(1962,1979)$ & \\
\hline & & $\begin{array}{l}\text { Philippines (1968, 1976-1984, 1987-1993, } \\
\text { 1998) }\end{array}$ & Thailand $(1984,1997,2000)$ & $\begin{array}{l}\text { Korea }(1962-1963,1966,1970,1975,1979- \\
1980,1997,2008)\end{array}$ & \\
\hline & & Sri Lanka $(1968,1977,1980,1983,1989)$ & Tunisig(12965, 1974, 1978, 1986) & Netherlands (2005) & \\
\hline & & $\begin{array}{l}\text { Zambia }(1977,1983-1986,1988-1996, \\
\text { 1998, 2000, 2008) }\end{array}$ & Turkey $(1971,1977-2001,2008)$ & Norway $(1982,1986,2008)$ & \\
\hline & & & & Portugal $(1976-1977,1981-1984,2005)$ & \\
\hline & & & & Spain $(1967,1977,1982,1993,2005)$ & \\
\hline
\end{tabular}




\begin{tabular}{|c|c|c|c|c|c|}
\hline Crisis & Low income & Lower middle income & Upper middle income & High OECD & High non-OECD \\
\hline \multirow[t]{8}{*}{$\overline{D O M}$} & Myanmar (1984) & Bolivia (1982-1984) & $\begin{array}{l}\text { Argentina (1982, 1989-1990, 2001-2005, } \\
\text { 2007-2010) }\end{array}$ & & \\
\hline & Zimbabwe (2006) & El Salvador (1981-1996) & Brazil $(1986-1987,1990,2002)$ & & \\
\hline & & Ghana $(1979,1982)$ & Dominican Republic (1975-2001) & & \\
\hline & & Indonesia (1997-1999) & Ecuador (1999) & & \\
\hline & & Nicaragua (1985-1990) & Mexico (1982) & & \\
\hline & & Philippines (1985-1987) & Panama (1988-1989) & & \\
\hline & & Sri Lanka (1996) & Peru (1985-1987) & & \\
\hline & & & Turkey (2001) & & \\
\hline \multirow[t]{14}{*}{ EXT } & Central African Republic $(1981,1983-2010)$ & Bolivia (1980-1984 1986-1997) & Algeria (1991-1996) & $\begin{array}{l}\text { Chile (1961, 1963, 1965, 1972, 1974-1975, } \\
\text { 1983-1990) }\end{array}$ & Singapore $(1981-1983,1986)$ \\
\hline & Kenya (1994-2003) & Egypt (1984) & $\begin{array}{l}\text { Argentina (1961-1965, 1982-1993, } 2001- \\
\text { 2005) }\end{array}$ & Greece (1961-1964) & $\begin{array}{l}\text { Uruguay }(1965,1983-1985,1987,1990- \\
1991,2003)\end{array}$ \\
\hline & Myanmar (2002-2010) & Ghana $(1966,1968,1970,1974,1987)$ & Brazil $(1961,1964,1983-1994,2002)$ & & \\
\hline & Zimbabwe (1965-1974, 2000-2009) & Guatemala $(1986,1989)$ & Costa Rica $(1962,1981,1983-1990)$ & & \\
\hline & & Honduras (1981-2010) & Dominican Republic $(1982-1994,2005)$ & & \\
\hline & & India $(1969,1972-1976)$ & Ecuador $(1982-1995,1999-2000,2008)$ & & \\
\hline & & Indonesia (1966-1970, 1998-2000, 2002) & Mexico (1982-1990) & & \\
\hline & & Morocco $(1983,1986-1990)$ & Panama (1983-1996) & & \\
\hline & & Nicaragua (1979-2010) & Peru $(1969,1976,1978,1980,1984-1997)$ & & \\
\hline & & Nigeria (1982-1992, 2001, 2004-2005) & South Africa $(1985-1987,1989,1993)$ & & \\
\hline & & $\begin{array}{l}\text { Paraguay }(1968-1969,1986-1992,2003- \\
\text { 2004) }\end{array}$ & Tunisia $(1963,1979-1982)$ & & \\
\hline & & Philippines $(1969,1976,1978,1980,1984-$ & Turkey $(1965,1978-1979,1982,2001)$ & & \\
\hline & & Sri Lanka $(1979,1981-1983)$ & & & \\
\hline & & Zambia (1983-1994) & & & \\
\hline \multirow[t]{2}{*}{ IND } & Kenya (1963) & Zambia (1966) & Algeria (1962) & & Singapore (1965) \\
\hline & Zimbabwe (1965) & & Malaysia (1963) & & \\
\hline \multirow[t]{13}{*}{ INF } & Central African Republic $(1971,1994)$ & Bolivia $(1973-1975,1979-1986,1991)$ & Algeria (1991-1995) & Australia $(1966,1975)$ & Singapore (1990-2002) \\
\hline & Kenya $(1984,1992-1994)$ & Egypt (1980, 1986-1987, 1989-1990, 1992) & $\begin{array}{l}\text { Argentina (1962, 1964-1967, 1971-1992, } \\
\text { 2002, 2006-2007) }\end{array}$ & $\begin{array}{l}\text { Chile (1962-1965, 1968-1980, 1983, 1985, } \\
\text { 1990-1991) }\end{array}$ & $\begin{array}{l}\text { Uruguay (1961, 1963-1969, 1971-1981, } \\
\text { 1983-1996) }\end{array}$ \\
\hline & $\begin{array}{l}\text { Myanmar (1966, 1973-1976, 1988-1998, } \\
\text { 2001-2003, 2006-2008) }\end{array}$ & EI Salvador $(1985-1987,1990,1993)$ & Brazil (1961-1969, 1971, 1974-1995) & Greece $(1986,1990)$ & \\
\hline & $\begin{array}{l}\text { Zimbabwe (1983-1984, 1991-1996, 1998- } \\
\text { 2008) }\end{array}$ & $\begin{array}{l}\text { Ghana }(1965,1973,1976-1984,1986-1990, \\
1993-1997,2000-2001,2003)\end{array}$ & China (1994) & Iceland (1970, 1974-1986, 1988-1989) & \\
\hline & & Guatemala $(1974,1986,1990-1991)$ & $\begin{array}{l}\text { Colombia (1963, 1973-1977, 1979-1982, } \\
\text { 1985, 1987-1996) }\end{array}$ & Italy $(1974,1980)$ & \\
\hline & & Honduras (1990-1991, 1994-1997) & $\begin{array}{l}\text { Costa Rica }(1974,1981-1983,1988,1991- \\
1992,1995)\end{array}$ & Japan (1980) & \\
\hline & & India (1973-1974) & $\begin{array}{l}\text { Dominican Republic (1980, 1984-1985, } \\
\text { 1988-1991, 2003-2004) }\end{array}$ & Korea $(1974,1980-1981)$ & \\
\hline & & $\begin{array}{l}\text { Indonesia (1961-1968, 1973-1974, 1979, } \\
\text { 1998-1999) }\end{array}$ & Ecuador $(1974,1983-2001)$ & Portugal $(1974,1982-1984)$ & \\
\hline & & Nicaragua $(1973,1979-1992,2008)$ & $\begin{array}{l}\text { Mexico (1976-1977, 1980-1991, 1995- } \\
\text { 1997) }\end{array}$ & Spain (1977) & \\
\hline & & $\begin{array}{l}\text { Nigeria }(1975,1977,1981,1983-1984, \\
\text { 1988-1989, 1992-1996) }\end{array}$ & Peru (1975-1994) & United Kingdom (1975) & \\
\hline & & $\begin{array}{l}\text { Paraguay }(1974,1979-1980,1984-1991, \\
\text { 1994) }\end{array}$ & Thailand (1974) & & \\
\hline & & Philippines (1975-1994) & Turkey (1977-2003) & & \\
\hline & & $\begin{array}{l}\text { Sri Lanka }(1980,1990,2008) \\
\text { Zambia }(1984-2003)\end{array}$ & 33 & & \\
\hline
\end{tabular}




\begin{tabular}{|c|c|c|c|c|c|}
\hline Crisis & Low income & Lower middle income & Upper middle income & High OECD & High non-OECD \\
\hline \multirow[t]{20}{*}{ STO } & Kenya $(1990-1992,1995-2002,2007-2008)$ & $\begin{array}{l}\text { India }(1962-1967,1974,1986-1987,1995- \\
1996,1998,2000-2001,2008)\end{array}$ & $\begin{array}{l}\text { Argentina }(1970-1973,1975,1977,1980- \\
1981,1983-1984,1986-1988,1990,1992, \\
1994,1998,2000-2001,2007-2008)\end{array}$ & $\begin{array}{l}\text { Australia }(1970-1971,1973-1974,1981- \\
1982,1990,2008)\end{array}$ & Singapore $(1999-2001,2008)$ \\
\hline & $\begin{array}{l}\text { Zimbabwe (1976-1978, 1980-1984, 1986, } \\
\text { 1990-1992, 1994-1995, 1997-1998, 2001- } \\
\text { 2004, 2006) }\end{array}$ & $\begin{array}{l}\text { Indonesia (1980-1987, 1991-1992, 1995, } \\
\text { 1998-1999, 2001-2003, 2009) }\end{array}$ & $\begin{array}{l}\text { Brazil }(1972,1986,1992,1998,2000-2002 \text {, } \\
\text { 2008) }\end{array}$ & $\begin{array}{l}\text { Austria (1961-1965, 1970-1975, 1977- } \\
\text { 1979, 1983-1984, 1987-1989, 1991-1992, } \\
\text { 2007-2008) }\end{array}$ & $\begin{array}{l}\text { Uruguay (1961-1975, 1981, 1983-1984, } \\
\text { 1988-1989) }\end{array}$ \\
\hline & & Morocco $(1980-1983,1999-2002)$ & $\begin{array}{l}\text { China (1993-1995, 2001-2002, 2004-2005, } \\
\text { 2008) }\end{array}$ & $\begin{array}{l}\text { Belgium (1964-1966, 1973-1974, 1976- } \\
\text { 1977, 1980-1981, 1990, 1999-2002, 2007- } \\
\text { 2008) }\end{array}$ & \\
\hline & & $\begin{array}{l}\text { Nigeria (1988-1989, 1992-1994, 1997- } \\
\text { 1999) }\end{array}$ & $\begin{array}{l}\text { Colombia (1961-1963, 1965-1966, 1970- } \\
\text { 1975, 1979-1980, 1982-1985, 1988-1989, } \\
\text { 1994-1996, 1998-2000, 2007-2008) }\end{array}$ & Canada $(1973-1974,2001-2002,2008)$ & \\
\hline & & Paraguay (1998-2000) & $\begin{array}{l}\text { Malaysia }(1974,1981-1982,1984-1985, \\
1994-1995,1997-1998,2008)\end{array}$ & $\begin{array}{l}\text { Chile }(1964-1967,1970,1972,1974-1975, \\
1981-1984,1995-1998,2008)\end{array}$ & \\
\hline & & $\begin{array}{l}\text { Philippines (1961-1969, 1973-1976, 1981- } \\
\text { 1982, 1987-1988, 1990, 1998, 2000-2001, } \\
\text { 2008) }\end{array}$ & $\begin{array}{l}\text { Mexico (1961-1962, 1966-1971, 1973- } \\
\text { 1975, 1980-1982, 1994-1996, 1998, 2000, } \\
\text { 2008) }\end{array}$ & $\begin{array}{l}\text { Denmark (1965-1967, 1969-1971, 1973- } \\
\text { 1974, 1976-1980, 1984, 1986-1987, 1992, } \\
\text { 2001-2002, 2008) }\end{array}$ & \\
\hline & & Turkey (1977-2003) & $\begin{array}{l}\text { Peru }(1961-1969,1973-1976,1981-1982, \\
1987-1988,1990,1998,2000-2001,2008)\end{array}$ & $\begin{array}{l}\text { Finland }(1963-1967,1974-1977,1989- \\
1991,2000-2002,2008)\end{array}$ & \\
\hline & & Zambia (1998-1999, 2001-2002) & $\begin{array}{l}\text { South Africa (1969-1971, 1973-1976, } 1995- \\
\text { 1998) }\end{array}$ & $\begin{array}{l}\text { France }(1963-1967,1970-1971,1973-1974, \\
1976-1977,1980-1982,1987,1990,1992- \\
1995,2000-2002,2008)\end{array}$ & \\
\hline & & & $\begin{array}{l}\text { Thailand (1979-1981, 1990, 1994-1998, } \\
\text { 2000) }\end{array}$ & $\begin{array}{l}\text { Greece }(1962-1966,1973-1985,1991- \\
1992,1994-1996,2000-2002,2008,2010)\end{array}$ & \\
\hline & & & $\begin{array}{l}\text { Turkey }(1988,1990-1992,1994-1995, \\
1998,2000-2002,2008)\end{array}$ & $\begin{array}{l}\text { Italy (1962-1964, 1970-1971, 1974-1977, } \\
\text { 1981-1982, 1987, 1990-1992, 2001-2002, } \\
\text { 2007-2008) }\end{array}$ & \\
\hline & & & & $\begin{array}{l}\text { Japan }(1962-1964,1973-1974,1990-1992, \\
1996-1998,2000-2002,2007-2008)\end{array}$ & \\
\hline & & & & $\begin{array}{l}\text { Korea }(1963-1966,1974,1978-1980,1989- \\
1991,1995-1997,2000,2008)\end{array}$ & \\
\hline & & & & $\begin{array}{l}\text { Netherlands (1965-1966, 1969-1971, 1973- } \\
1974,2000-2002,2008)\end{array}$ & \\
\hline & & & & $\begin{array}{l}\text { Norway }(1962,1964-1967,1971,1974- \\
1975,1977-1978,1982,1986-1987,1990- \\
1992,1998,2001-2002,2008)\end{array}$ & \\
\hline & & & & $\begin{array}{l}\text { Portugal (1961-1962, 1974, 1978, 1981, } \\
\text { 1983, 1988, 1990-1992, 2000-2002) }\end{array}$ & \\
\hline & & & & $\begin{array}{l}\text { Spain (1964-1967, 1974-1980, 1982, 1990, } \\
\text { 2000-2002) }\end{array}$ & \\
\hline & & & & Sweden (1966, 1969-1970, 1976-1977, & \\
\hline & & & & 1990-1992, 2000-2002, 2008) & \\
\hline & & & & $\begin{array}{l}\text { United Kingdom (1969-1970, 1973-1974, } \\
\text { 2000-2002, 2008) }\end{array}$ & \\
\hline & & & & $\begin{array}{l}\text { United States }(1973-1974,1977-1982, \\
1989-1991,2000-2002,2008)\end{array}$ & \\
\hline
\end{tabular}

2/ Source: Reinhardt and Rogoff (2010). 


\section{Appendix 3: Details definition of crises (Reinhart and Rogoff, 2009)}

- BAN: A bank run that leads to the closure, merger or takeover by the public sector of one or more financial institutions. If no runs, the closure, merger and takeover or large-scale government assistance of an important financial institution (or group of institutions), that marks the start of a string of similar outcomes for other financial institutions.

- CUR: An annual depreciation versus the US dollar (or the relevant anchor currencyhistorically the UK pound, the French franc or the German DM and presently the euro) of 15 percent or more.

- EXT: A sovereign default is the failure to meet a principal or interest payment on the due date (or within the specified grace period). The episodes also include instances where rescheduled debt is ultimately extinguished in terms less favorable than the original obligation.

- DOM: Like EXT, a sovereign default is the failure to meet a principal or interest payment on the due date (or within the specified grace period). The episodes also include instances where rescheduled debt is ultimately extinguished in terms less favorable than the original obligation. In addition, domestic debt crises have involved the freezing of bank deposits and or forcible conversions of such deposits from dollars to local currency.

- INF: An annual inflation rate of 20 percent or higher. We also examine separately the incidence of more extreme cases where inflation exceeds 40 percent per annum.

- STO: A cumulative decline of -25 percent or more in real equity prices. 

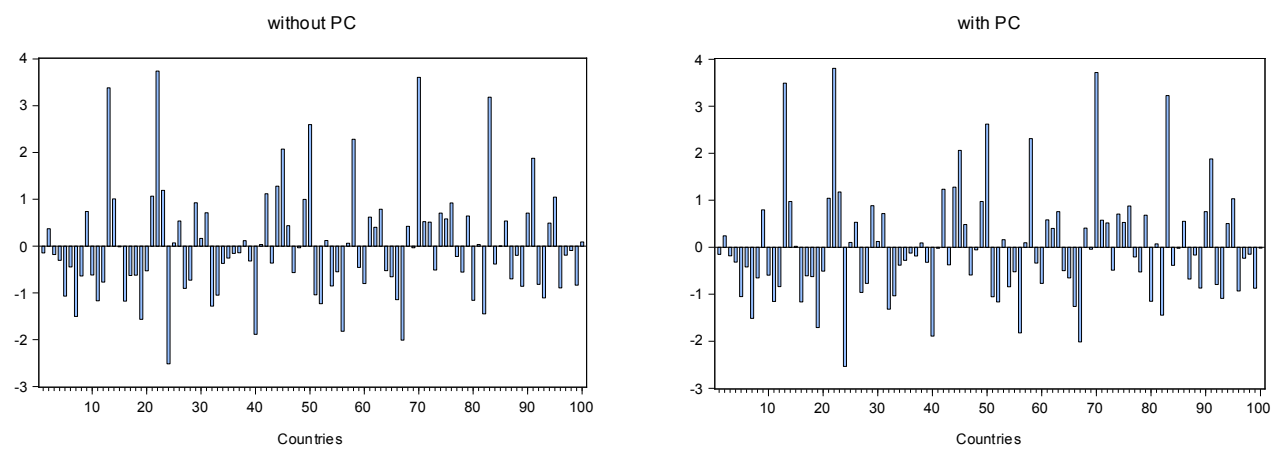

Figure 1: Fixed effects for the full model, 1960-2010
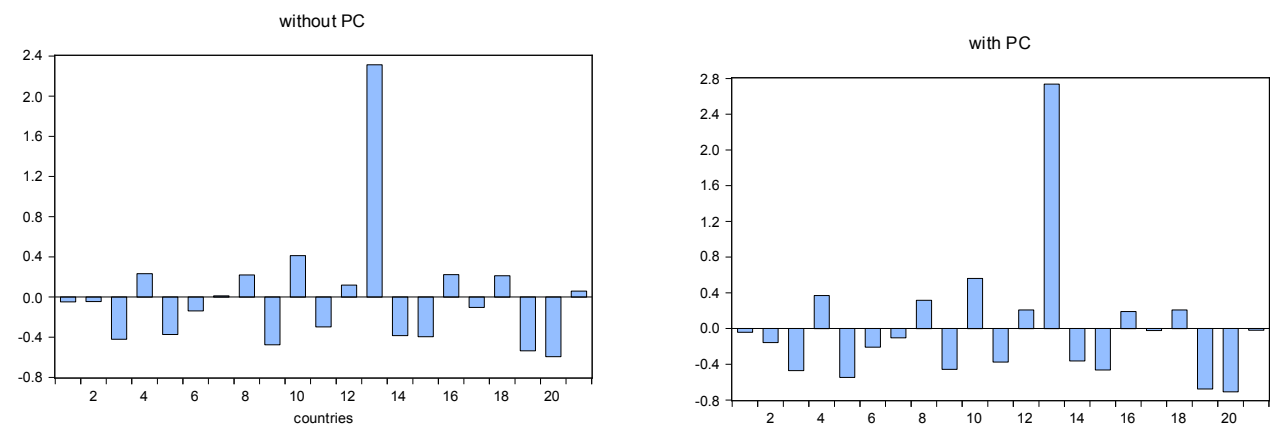

Figure 2: Fixed effects for high income OECD countries, 1960-2010

\section{Appendix 4: Fixed effects}

